Cecília Korber Gonçalves

\title{
PIRÓLISE E COMBUSTÃo DE RESÍDUOS PLÁSTICOS
}

Dissertação apresentada à Escola Politécnica da Universidade de São Paulo para obtenção do título de Mestre em Engenharia.

São Paulo

2007 
Cecília Korber Gonçalves

\section{PIRÓLISE E COMBUSTÃo DE RESÍDUOS PLÁSTICOS}

Dissertação apresentada à Escola Politécnica da Universidade de São Paulo para obtenção do título de Mestre em Engenharia.

Área de Concentração:

Engenharia de Materiais

Orientador:

Prof. Dr. Jorge Alberto Soares Tenório

São Paulo 
Gonçalves, Cecilia Korber

Pirólise e combustão de resíduos plásticos / C.K. Gonçalves. - São Paulo, 2007.

p.

Dissertação (Mestrado) - Escola Politécnica da Universidade de São Paulo. Departamento de Engenharia Metalúrgica e de Materiais.

1.Combustão 2.Pirólise 3.Plásticos (Reciclagem) I.Universidade de São Paulo. Escola Politécnica. Departamento de Engenharia Metalúrgica e de Materiais II.t. 
A meus pais, irmã e amigos 
Vista do crepúsculo, no final do século

Está envenenada a terra que nos enterra ou desterra.

Já não há ar,só desar.

Já não há chuva, só chuva ácida.

Já não há parques, só parkings.

Já não há sociedades, só sociedades anônimas.

Empresas em lugar de nações.

Consumidores em lugar de cidadãos.

Aglomerações em lugar de cidades.

Não há pessoas, só públicos.

Não há realidades, só publicidades.

Não há visões, só televisões.

Para elogiar uma flor, diz-se: "Parece de plásticos".

(Eduardo Galeano) 


\section{AGRADECIMENTOS}

Pela orientação, amizade e confiança desde 1999, no meu primeiro emprego, meus sinceros agradecimentos ao Prof. Dr. Jorge A. S. Tenório.

Ao Prof. Dr. Yiannis A. Levendis cuja contribuição para o entendimento e análise dos ensaios realizados foi de fundamental importância para a execução deste trabalho. Agradeço também pelo acolhimento em seu laboratório na Northeastern University - Boston, MA - USA.

Ao Dr. Joel B. Carlson e ao Joseph Jordan do United States Army Natick Research Center pela realização das análises dos $P A H$ 's.

Aos amigos Ali e Paula, pela companhia no laboratório e fora dele, o que tornou muito mais agradável todo o período em Boston.

A todos os amigos que fizeram e ainda fazem parte do grupo de trabalho (Jean, Denise, Vivian, Viviane, Josiane, Márcia, Jefferson, Alexandre, José Roberto a lista é infindável). Vocês são uma equipe da qual eu sempre me orgulhei de participar.

À Prof. Patricia Matai pela indicação, insistência e ajuda a receber a bolsa do mestrado.

À Schlumberger Foundation pelo financiamento deste trabalho através da concessão bolsa Faculty for the Future nos anos de 2005 a 2007.

Ao Professor Dr. Massola, Sr. Vicente, Sr. Yoshida e funcionários da FUSP pela assistência durante os anos de trabalho.

Aos professores e funcionários do Depto. de Eng. Metalúrgica e de Materiais que sempre estiveram prontos a me ajudar nas mais diversas ocasiões.

Aos meus pais e à minha irmã pelo amor e carinho - sem vocês seria inviável. 


\section{RESUMO}

Dois milhões de toneladas por ano de resíduos plásticos são gerados no Brasil. Apenas $16,5 \%$ em massa deste resíduo plástico são mecanicamente reciclados, a maior parte restante é levada a aterros ou lixões. Todo este material poderia ser incinerado e, desta forma reduzir em até $90 \%$ a massa do volume aterrado, e seu conteúdo energético seria usado para gerar vapor ou energia. Esta investigação foi feita sobre os produtos de combustão incompleta emitidos da pirólise e combustão em estado estacionário do polietileno e poliestireno em um forno vertical de dois estágios, eletricamente aquecido. Separadamente, os polímeros na forma pulverizada foram pirolisados em temperatura constante de $1000^{\circ} \mathrm{C}$ e, depois da mistura com $\mathrm{N}_{2} / \mathrm{O}_{2}$, os produtos de pirólise foram queimados a 900,1000 e $1100^{\circ} \mathrm{C}$. Os testes foram conduzidos com $21 \%$ de $\mathrm{O}_{2}$ em volume no forno de oxidação. Diferentes razões de combustível e ar foram usadas no forno de combustão, pela variação da taxa de alimentação de polímero no forno de pirólise. A motivação para a combustão indireta de PE e PS foi obter a combustão nominalmente prémisturada dos gases de pirólise com ar, assim, obtendo menores emissões dos produtos de combustão incompleta comparativamente à combustão direta do polímero sólido. Este trabalho examinou os efeitos da temperatura de combustão e a razão equivalente de ar e combustível. Os efluentes da pirólise e combustão foram analisados, e as emissões de $\mathrm{CO}, \mathrm{CO}_{2}, \mathrm{O}_{2}$, hidrocarbonetos leves, hidrocarbonetos policíclicos aromáticos e materiais particulados foram mensurados. Ainda, o material particulado foi caracterizado quanto ao tamanho das partículas. Foi observado que enquanto a quantidade de gás de pirólise diminuiu com o aumento da taxa de alimentação do polímero, sua composição permaneceu praticamente independente da taxa de alimentação. As emissões de $\mathrm{CO}_{2}$ foram máximas perto da razão equivalente 1, enquanto as emissões de $\mathrm{CO}$ aumentaram com o aumento da razão equivalente. As emissões totais de hidrocarbonetos leves e PAH na combustão aumentaram tanto com o aumento da razão equivalente, quanto do aumento da temperatura. A maior parte do material particulado teve o tamanho menor que um micrometro. No geral, as emissões de PAH e material particulado da combustão indireta de PE e PS foram uma ordem de grandeza menor que a emissão correspondente da combustão direta e heterogênea do polímero sólido, obtida em outros trabalhos. Como a pirólise destes polímeros requer uma entrada nominal de calor mínima em relação à quantidade de calor gerada na sua combustão, a implantação desta técnica pode ser vantajosa.

Palavras-chave: Plásticos. Pirólise. Combustão. Resíduos. PAH. Material particulado. 


\section{ABSTRACT}

Two millions tons/year of plastic wastes are generated in Brazil. Only $16.5 \%$ of this plastic waste is mechanically recycled, the rest is mostly landfilled. All these material could be incinerated, in a way to reduce by $90 \%$ the volume of landfilled waste, and use its energy content to supply energy. This investigation was conducted on pollutants emitted from steady-flow pyrolysis and combustion of polyethylene and polystyrene in a two-stage electrically-heated vertical furnace. Separately, the polymers, in pulverized form, were first pyrolyzed at constant temperature of $1000^{\circ} \mathrm{C}$ and subsequently their pyrolyzates were burned at 900,1000 and $1100^{\circ} \mathrm{C}$, upon mixing with air. Tests were conducted with $21 \%$ of $\mathrm{O}_{2}$ and different fuel to air equivalence ratios in the oxidizer furnace, by keeping the flow of gases and changing the feed rate of polymer in the pyrolyzer furnace. The motivation for this indirect combustion of PE and PS was to attain nominally-premixed combustion of the pyrolyzate gases with air, thereby achieving lower pollutant emissions than those from direct combustion of the solid polymer. This work examined the effects of the combustion temperature, as well as of the polymer feed rate and the resulting fuel to air equivalence ratio. The effluents of pyrolysis and combustion were analyzed for fixed gases $\left(\mathrm{CO}, \mathrm{CO}_{2}, \mathrm{O}_{2}\right)$, light hydrocarbons, polycyclic aromatic hydrocarbons and particulate matter. It was found that whereas the amount of pyrolysis gas decreased with increasing polymer feed rate, its composition was nearly independent of the feed rate. $\mathrm{CO}_{2}$ emissions peaked at an equivalence ratio near unity, while the $\mathrm{CO}$ emissions increased with increasing equivalence ratio. The total light hydrocarbon and PAH emissions of combustion increased both with increasing equivalence ratio and with temperature. The generated particulates were mostly submicronmeter in size. Overall, PAH and soot emissions from indirect burning of PE and PS were an order of magnitude lower than corresponding emissions from direct heterogeneous burning of the solid polymer, obtained elsewhere. As pyrolysis of these polymers requires a nominal heat input that amounts to a diminutive fraction of the heat released during its combustion, implementation of this technique is deemed advantageous.

Keywords: Plastic. Pyrolysis. Combustion. Wastes. PAH. Particulate Matter. 


\section{SUMÁRIO}

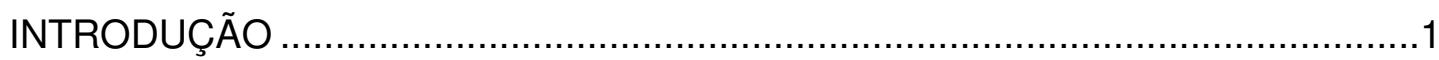

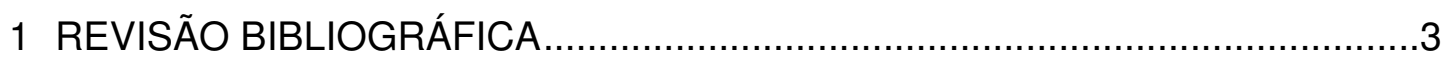

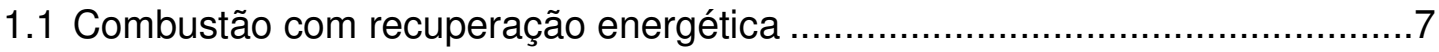

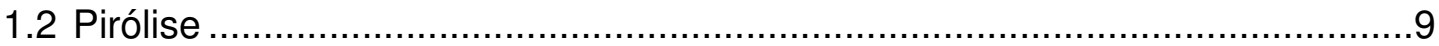

1.2.1 Pirólise dos polímeros PE e PS ………................................................10

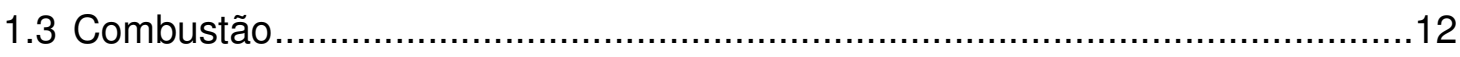

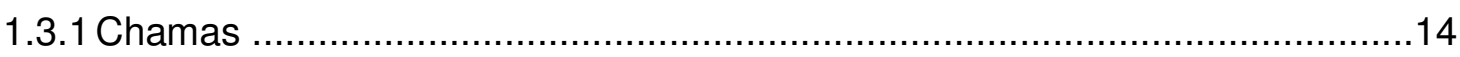

1.3.2 Produtos de combustão incompleta........................................................16

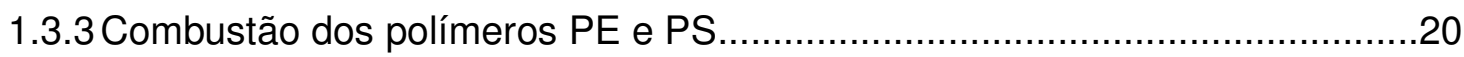

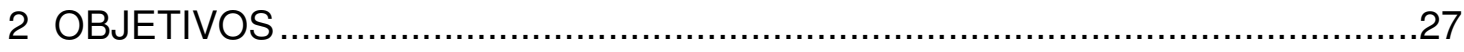

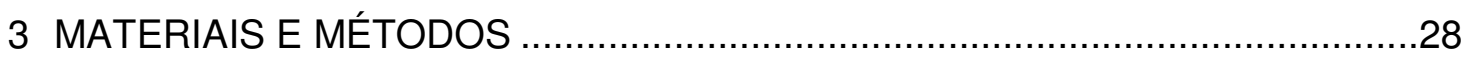

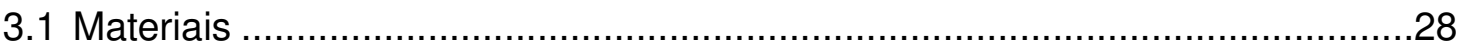

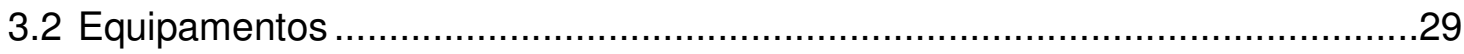

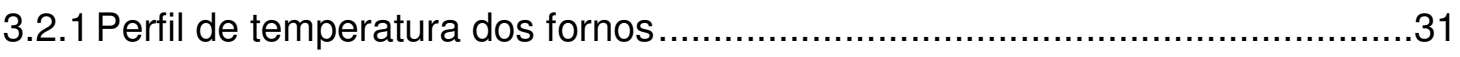

3.2.2 Cálculo e simulação da gaseificação da partícula dos polímeros ....................33

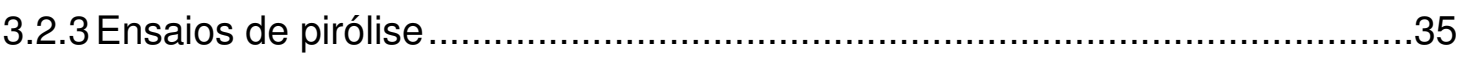

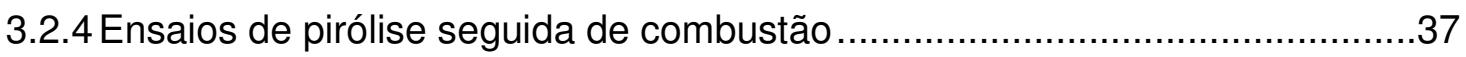

3.2.5 Caracterização do material particulado .........................................................

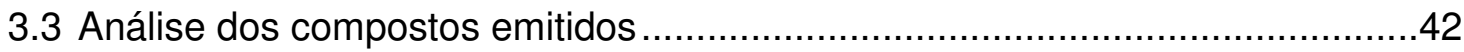

3.3.1 Hidrocarbonetos leves por cromatografia gasosa ........................................42

3.3.2 Gases $\mathrm{CO}, \mathrm{CO}_{2}$ e $\mathrm{O}_{2}$ por cromatografia gasosa ........................................43

3.3.3 Gases $\mathrm{CO}, \mathrm{CO}_{2}$ e $\mathrm{O}_{2}$ por analisadores online .........................................43

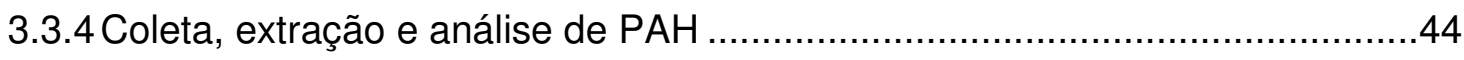

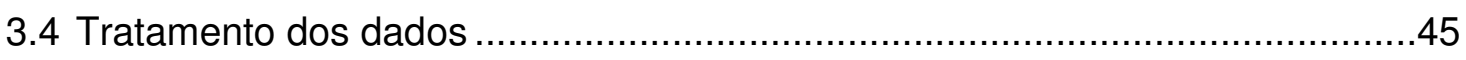

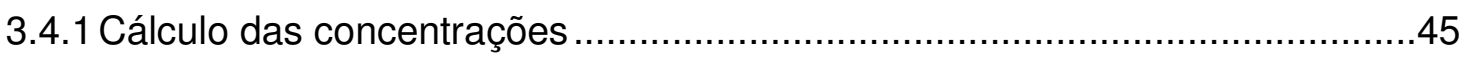

3.4.2 Cálculo das porcentagens de fração mássica ............................................46

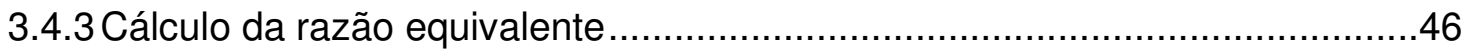

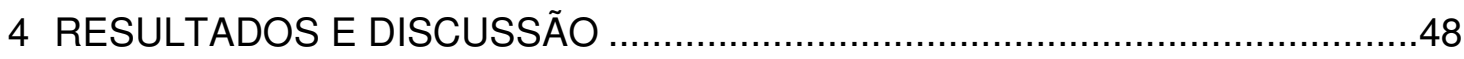

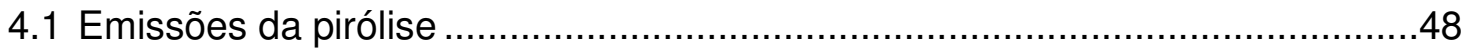

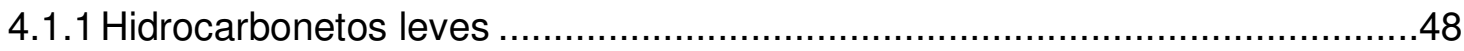

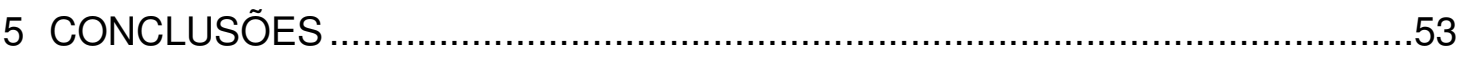




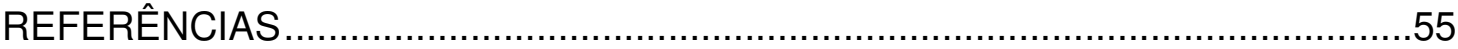




\section{LISTA DE FIGURAS}

Figura 1 - Porcentagem de distribuição da venda de resinas em 2005 [7] .............4

Figura 2 - Resinas geradas e recicladas mecanicamente no RSU brasileiro em 2003

[5]. 5

Figura 3 - Seqüência da queima de um copo de PS expandido.......................... 8

Figura 4 - a) Chama pré-misturada e b) Chama difusa. ..................................... 15

Figura 5 - Etapas da formação das partículas de fuligem. ................................ 19

Figura 6 - Emissões teóricas dos produtos de combustão de PE. .......................20

Figura 7 - Emissões teóricas dos produtos de combustão de PS. ........................20

Figura 8 - Esquema do forno utilizado em diversos estudos na NU......................22

Figura 9 - Esquema do forno utilizado nos estudos de sistema contínuo na NU......24

Figura 10 - Partículas de 38-125 $\mu$ m de diâmetro (zoom 4X) a) PS e b) PE...........28

Figura 11 - a) Forno utilizado nos ensaios e b) Esquema ilustrativo. ....................29

Figura 12 - Elementos aquecedores e o isolamento térmico..............................30

Figura 13 - Detalhe do sistema de injeção das partículas. ................................ 31

Figura 14 - Venturi entre os fornos para injeção de ar. ..................................... 31

Figura 15 - Perfil de temperatura nos fornos de vaporização e oxidação.................32

Figura 16 - Diâmetro de uma partícula de PE versus a) tempo para gaseificar e b)

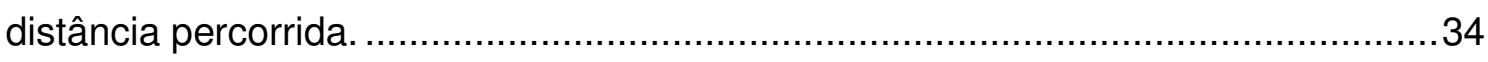

Figura 17 - Diâmetro de uma partícula de PS versus a) tempo para gaseificar e b)

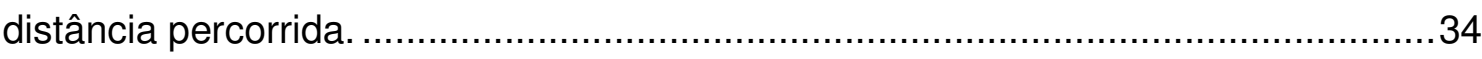

Figura 18 - Forno usado nos ensaios de pirólise com os pontos de coletas de produtos. 36

Figura 19 - Sistema de coleta de material particulado total, PAH e HL. 37 
Figura 20 - Forno usado nos ensaios de pirólise seguida de combustão, com os pontos de coletas de produtos. 38

Figura 21 - Detalhe do sistema de coleta de HL no venturi..............................40

Figura 22 - Aparato de coleta de material particulado para caracterização.............41

Figura 23 - Esquema do separador de partículas.......................................42

Figura 24 - Aparelho de cromatografia (análises de $\mathrm{HL}$ e $\mathrm{N}_{2}, \mathrm{CO}, \mathrm{CO}_{2}$ e $\mathrm{O}_{2}$ ).........42

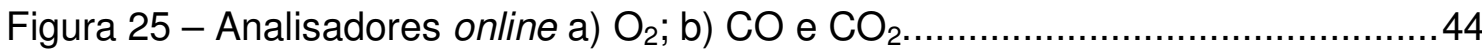

Figura 26 - Porcentagem da fração mássica dos HL da pirólise de a) PE e b) PS...48 Figura 27 - Emissão de HL total e individuais na pirólise e pirólise seguida de

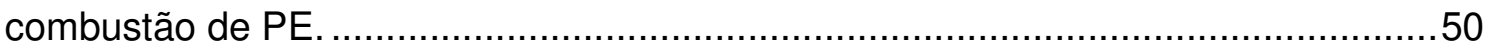

Figura 28 - Emissão de HL total e individuais na pirólise e pirólise seguida de

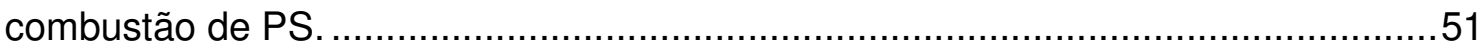




\section{LISTA DE TABELAS}

Tabela 1 - Destino do RSU em \% de peso (2002) [5]..................................

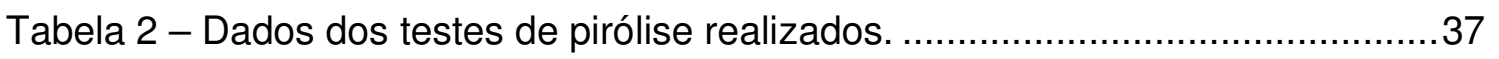

Tabela 3 - Dados dos testes de pirólise seguida de combustão com PS.................39

Tabela 4 - Dados dos testes de pirólise seguida de combustão com partículas de

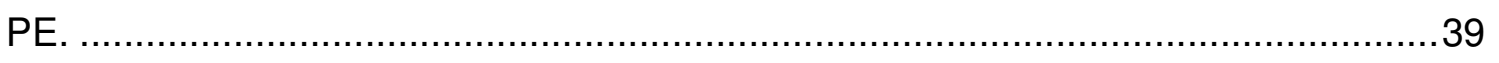

Tabela 5 - Testes realizados, temperaturas e número de testes............................39

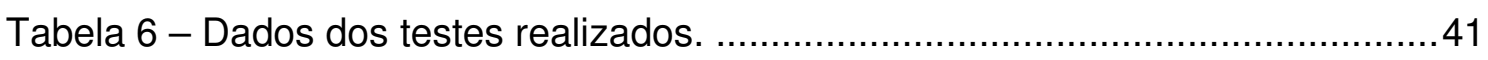




\section{LISTA DE ABREVIATURAS}

$\begin{array}{ll}\text { amu } & \text { unidade de massa atômica } \\ \text { APC } & \text { American Plastic Council } \\ \text { APME } & \text { Association of Plastic Manufacturers from Europe } \\ \text { CA } & \text { relação mássica de combustível e ar } \\ \text { EB } & \text { etilbenzeno } \\ \text { EPA } & \text { Environmental Protection Ageny } \\ \text { HL } & \text { hidrocarboneto leve } \\ \text { Ipm } & \text { litros por minuto } \\ \text { NU } & \text { Northeastern University, Boston, MA, EUA } \\ \text { PA } & \text { poliamida } \\ \text { PAH } & \text { hidrocarbonetos policíclicos aromáticos } \\ \text { PC } & \text { policarbonato } \\ \text { PCI ou PIC } & \text { produto de combustão incompleta } \\ \text { PE } & \text { polietileno } \\ \text { PEAD } & \text { polietileno de alta densidade } \\ \text { PEBD } & \text { polietileno de baixa densidade } \\ \text { PEBDL } & \text { polietileno de baixa densidade linear } \\ \text { PET } & \text { poli tereftalato de etileno } \\ \text { PP } & \text { polipropileno } \\ \text { PS } & \text { poliestireno } \\ \text { PVC } & \text { policloreto de vinila } \\ \text { RSU } & \text { resíduo sólido urbano } \\ \text { S } & \text { estireno } \\ \text { XAD-4 } & \text { resina adsorvente de PAH (nome comercial) } \\ & \\ \text { PA } & \text { ind }\end{array}$




\section{INTRODUÇÃO}

Um dos problemas de maior relevância para a sociedade contemporânea é o gerenciamento e disposição de resíduos sólidos, entre os quais o plástico. Diversas técnicas são utilizadas mundialmente para o aproveitamento deste material, como a reciclagem mecânica (a mais difundida no Brasil), a reciclagem química, a cocombustão e o aproveitamento energético (mais utilizado nos países desenvolvidos como Suíça, Holanda e Dinamarca) [1].

A reciclagem mecânica de produtos plásticos é a forma mais simples de recuperação deste material, porém nem sempre esta técnica mostra-se economicamente sustentável, visto que usualmente o material é uma mistura de diversos tipos de polímeros que se encontra contaminada por resíduos orgânicos [1]. Para os produtos que não atendem aos critérios da reciclagem mecânica, a reciclagem química e a recuperação energética em incineradores são processos alternativos para o aproveitamento do resíduo e sua energia.

O principal problema na incineração de resíduos é a mistura imperfeita do ar com o combustível, onde é criado um ambiente propício para as emissões de produtos de combustão incompleta $(\mathrm{PCl})$. Essa mistura imperfeita acontece porque 0 combustível consiste de partes sólidas que precisam fundir e pirolisar antes de misturar com o oxigênio.

Para obter uma boa mistura é crucial minimizar as complicações físicas da mistura dos gases oxidantes com o combustível sólido. De modo a solucionar este problema, os plásticos podem ser convertidos por pirólise em uma mistura gasosa, que pode ser usada como combustível. Este combustível gasoso pode ser homogeneamente misturado com ar e então queimado sob condições de baixa emissão de poluentes [2].

Ao contrário do que se possa imaginar, pirolisar o combustível sólido antes da combustão é energeticamente viável, já que apenas $1 \%$ do conteúdo energético do polietileno (PE) é requerido para gaseificar este combustível antes da combustão, e menos de 4\% para o poliestireno (PS) [3]. De fato, o conteúdo energético da maioria dos plásticos é comparável ao de combustíveis de primeira linha como a gasolina e óleo de aquecimento (cerca de $45 \mathrm{MJ} / \mathrm{kg}$ ), e é ainda maior do que o carvão (cerca de $30 \mathrm{MJ} / \mathrm{kg}$ ) [4]. 
Este estudo será focado no polietileno, que é o resíduo plástico mais abundante [5] e no poliestireno, que tem na sua estrutura molecular um anel aromático que aumenta sua propensão a formar os hidrocarbonetos policíclicos aromáticos (polycyclic aromatic hydrocarbon - PAH) e, por conseguinte, materiais particulados (fuligem).

Primeiramente, serão apresentados os principais produtos da pirólise dos polímeros em diferentes taxas de alimentação do forno. Em seguida, serão apresentadas as emissões de produtos de combustão indireta, isto é, o processo de pirólise seguido de combustão em fluxo contínuo, sob diversas temperaturas e razões equivalentes.

Foram medidas e analisadas as emissões de $\mathrm{CO}, \mathrm{CO}_{2}$, hidrocarbonetos leves, hidrocarbonetos policíclicos aromáticos e material particulado (fuligem). Os produtos da pirólise serão comparados com os produtos da combustão indireta, e assim verificar a formação e consumo dos principais compostos. Os resultados das emissões da pirólise e da combustão indireta serão comparados com a literatura sobre a combustão direta dos polímeros sólidos. Espera-se que as emissões de produtos de combustão incompleta da pirólise seguida da combustão sejam menores que a combustão direta. 


\section{REVISÃO BIBLIOGRÁFICA}

Os plásticos são materiais orgânicos formados de macromoléculas, sintetizados principalmente dos derivados de petróleo. Eles têm baixa densidade, baixa condutividade térmica e elétrica, alta resistência à corrosão e baixa taxa de degradação. Além disso, os plásticos são facilmente moldáveis em formatos desejados, duráveis e têm baixo custo de produção [6].

Segundo o Conselho Americano do Plástico (APC - American Plastic Council), aproximadamente $30 \%$ dos plásticos são utilizados em embalagens e $21 \%$ em produtos descartáveis (consumer and institutional, compreendido por produtos descartáveis, de escritório, de segurança, de laboratório e da área de saúde), conforme mostrado na Figura 1 [7].

A reciclagem mecânica consiste do processo de derretimento do plástico sólido com equipamentos de processos convencionais. O principal desafio enfrentado na reciclagem mecânica deste material é a coleta, separação dos outros resíduos sólidos urbanos e separação dos diferentes tipos de plásticos. Usualmente estes materiais estão contaminados com areia, óleos e matéria orgânica, o que inviabiliza economicamente a reciclagem mecânica e o pré-tratamento [1]. Por essa razão, a maior parte dos polímeros reciclados mecanicamente vem de materiais de fácil identificação e separação, como as garrafas de poli tereftalato de etileno (PET), garrafas de PE e plásticos do setor automotivo e eletro-eletrônico [8]. 


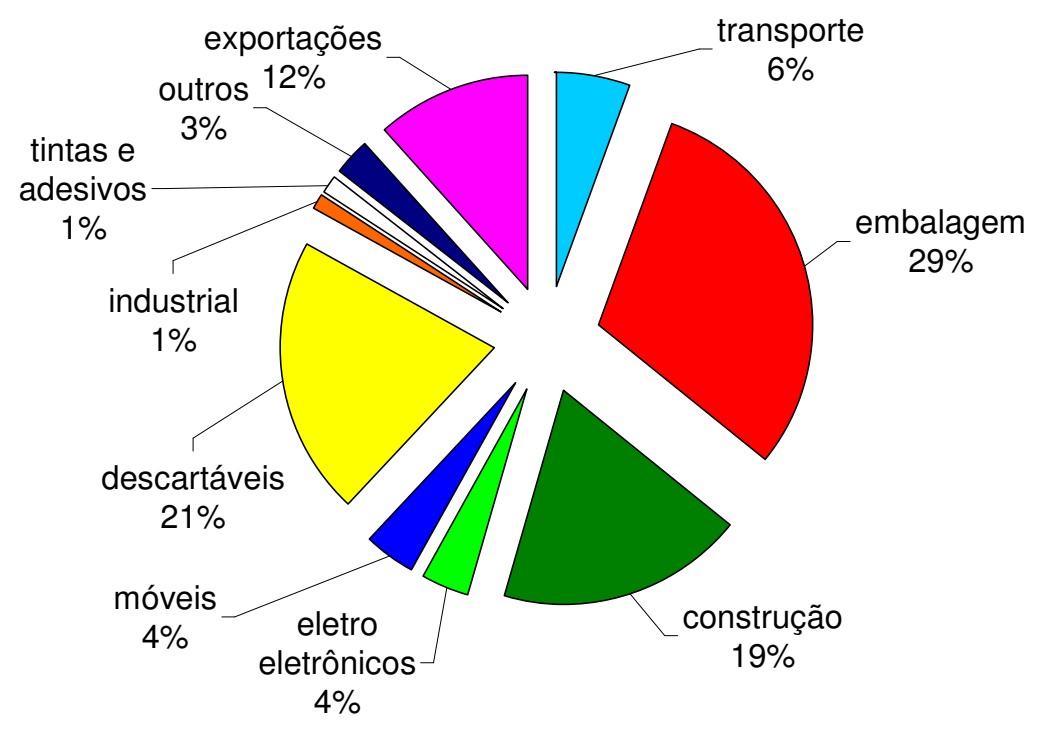

Figura 1 - Porcentagem de distribuição da venda de resinas em 2005 [7].

A geração total de plásticos nos Estados Unidos e Europa no ano de 2003 foi de 29 e 21,5 milhões de toneladas, respectivamente [9,10]. Neste mesmo ano, a geração total de plásticos no Brasil foi de apenas 2,18 milhões de toneladas, sendo aproximadamente $50 \%$ na região sudeste. A distribuição por tipo de resina da geração e reciclagem mecânica dos plásticos no Brasil em 2003, está apresentado na Figura 2. Observa-se que $45 \%$ do resíduo plástico gerado é de PE (incluído o de alta densidade, PEAD; baixa densidade, PEBD; e baixa densidade linear, PEBDL) e representa $40 \%$ dos plásticos reciclados mecanicamente. Porém, pela sua facilidade de identificação e coleta, o PET é o plástico mais reciclado mecanicamente (cerca de $40 \%$ ), apesar de representar menos de $20 \%$ das resinas plásticas geradas no resíduo sólido [5]. 


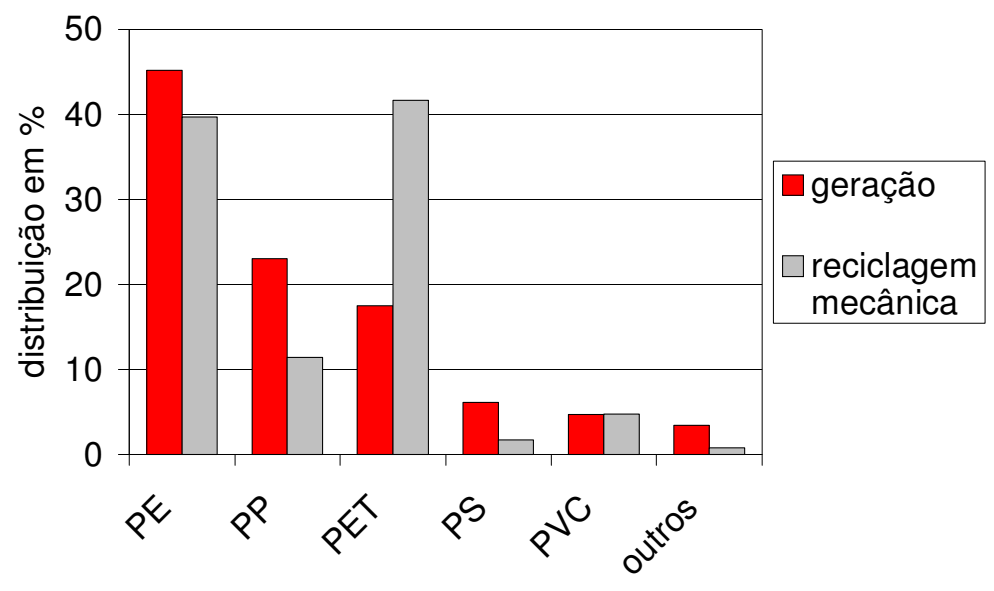

Figura 2 - Resinas geradas e recicladas mecanicamente no RSU brasileiro em 2003 [5].

Na Tabela 1 são apresentados os principais destinos do resíduo sólido urbano em diversos países. Nota-se que a maior parte do resíduo sólido nos países em desenvolvimento não é recuperado, sendo dispostos em aterros, ou lixões, como no Brasil e México [5]. Somente países mais desenvolvidos apresentam índices de incineração com recuperação energética mais elevados do que a disposição em aterros.

A relação entre o método de disposição e o nível de desenvolvimento econômico dos países pode ser observada também no consumo per capita anual de polímeros. O país que mais consome polímeros são os Estados Unidos, seguido pela Itália, Alemanha e Canadá (entre 0,07-0,09 t/hab/ano), porém o Brasil apresenta o consumo per capita aproximado ao do México, Indonésia e China (cerca de 0,02 t/hab/ano) [6]. 
Tabela 1 - Destino do RSU em \% de peso (2002) [5].

\begin{tabular}{|c|c|c|c|c|}
\hline País & Aterros (\%) & $\begin{array}{c}\text { Incineração com } \\
\text { recuperação } \\
\text { energética } \\
\end{array}$ & Compostagem & $\begin{array}{c}\text { Reciclagem } \\
\text { mecânica }\end{array}$ \\
\hline Brasil & 90 (aterros ou lixões) & - & 1,5 & 8 \\
\hline México & 97,6 (aterros ou lixoes) & - & 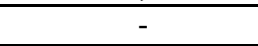 & 2,4 \\
\hline $\begin{array}{l}\text { Estados } \\
\text { Unidos }\end{array}$ & 55,4 & 15,5 & \multicolumn{2}{|c|}{29,1 (compostagem + reciclagem) } \\
\hline Alemanha & 50 & 30 & 5 & 15 \\
\hline França & 48 & 40 & \multicolumn{2}{|c|}{12 (compostagem + reciclagem) } \\
\hline Suécia & 40 & 52 & 5 & 3 \\
\hline Austrália & 80 & $<1$ & Insignificante & 20 \\
\hline Israel & 87 & - & - & 13 \\
\hline Grécia & 95 (aterros ou lixoes) & - & - & 5 \\
\hline Itália & 80 & 7 & 10 & 3 \\
\hline Reino Unido & 83 & 8 & 1 & 8 \\
\hline Holanda & 12 & 42 & 7 & 39 \\
\hline Suíça & 13 & 45 & 11 & 31 \\
\hline Dinamarca & 11 & 58 & 2 & 29 \\
\hline
\end{tabular}

No ano de 2004, o índice de reciclagem de plásticos pós-consumidos no Brasil, de 16\%, só foi superado pela Alemanha, Áustria e Estados Unidos [1], sendo que em alguns países a prática é impositiva e regulada por legislações complexas e custosas para a população local, diferentemente do Brasil, onde a reciclagem acontece de forma espontânea. $O$ fato do Brasil estar entre os primeiros países no índice de reciclagem mecânica, se deve ao grande número de pessoas envolvidas no processo de coleta do material (11.500 empregos diretos, sendo 500 mil catadores de ruas) e empresas recicladoras (490 no Brasil), muitas das quais informais [1, 11].

Do ponto de vista da conservação das fontes de matéria-prima, qualquer forma de reciclagem é desejável e deve ser incentivada. Na prática, contudo, deve ser pesado o custo da energia usada na reciclagem e os impactos do resíduo no meio ambiente.

Dessa forma, demonstradas as limitações técnicas e econômicas da reciclagem mecânica de plásticos pós-consumidos, salienta-se a existência de alternativas para a recuperação e aproveitamento dos plásticos, entre elas, a reciclagem química por solvólise, por termólise e a recuperação energética do material pela combustão [12].

O processo de solvólise consiste na reversão das reações de formação dos polímeros, obtendo seus monômeros originais. É usado para a reciclagem de polímeros como o PET, a poliamida (PA) e o policarbonato (PC) [6], entretanto, este 
processo não pode ser aplicado a polímeros com reação de formação irreversível, como o PP (polipropileno), PS e PE.

Para os polímeros citados (PP, PS e PE) é possível aplicar o processo de termólise, na qual a gaseificação e liquefação dos polímeros pela aplicação de calor os transforma em óleos, ceras e gases, que podem ser usados como combustível ou como matéria-prima para a produção de outros compostos químicos [8].

Por fim, a recuperação energética dos polímeros é possível pela combustão, processo em que a energia liberada pode ser aproveitada para produzir vapor ou energia elétrica [12]. Na co-combustão, duas ou mais substância sofrem a combustão, com o intuito de aproveitar o conteúdo energético e/ou utilizar algum componente presente nos materiais. Como exemplo de utilização deste sistema pode-se citar a adição de pneus aos fornos de cimento.

Dessa forma, para diminuir a quantidade de resíduos plásticos dispostos nos aterros e lixões do Brasil, é possível, além de incentivar a reciclagem mecânica, implantar a combustão com recuperação de energia em incineradores, utilizando-se para tanto as tecnologias já existentes em diversos países.

\subsection{Combustão com recuperação energética}

Em regiões onde a energia elétrica é gerada primariamente pela queima de carvão, a substituição de carvão por plástico resulta na co-geração de eletricidade e vapor, e diminuição da matéria-prima utilizada na queima. Essa substituição pode ser benéfica em termos de redução de emissões causadoras do efeito estufa [13].

Além de reduzir a quantidade de plásticos que necessitam de disposição em mais de $90 \%$ de seu volume, a recuperação energética dos plásticos pode ter outras vantagens, como a conservação de recursos fósseis não renováveis. Isso se deve ao fato da produção de plásticos usar aproximadamente $8 \%$ da produção de petróleo do mundo, sendo $4 \%$ como matéria-prima e $4 \%$ na fabricação e consumo de energia [14]. Outra vantagem pode ser a destruição de contaminantes perigosos, já que a temperatura pode atingir mais de $900^{\circ} \mathrm{C}$ [15].

Em países líderes em desenvolvimento ambiental, como a Suíça e Dinamarca, mais de $60 \%$ do conteúdo energético do resíduo sólido municipal é utilizado para fornecimento de energia [8]. Isso ocorre porque estes países aceitam, para os materiais que não podem ser reciclados, a recuperação de energia como 
uma alternativa à disposição em aterros. Na França, um estudo concluiu que a recuperação da energia de resíduos triturados economizaria 120.000 t/ano de petróleo, valor correspondente a $50 \%$ do consumo diário de petróleo na França no ano de 1992 [8].

A associação dos fabricantes de plástico da Europa (APME) conduziu experimentos no uso de películas de PE degradado removido de estufas como combustível auxiliar na queima de carvão em unidades de geração de energia térmica na Espanha (co-combustão). A película degradada pela luz do sol e que não pode ser reciclada foi picada e alimentada na unidade a uma taxa de $3 \mathrm{t} / \mathrm{h}$ junto com o carvão. Como o plástico tem um valor calorífico $66 \%$ mais alto que o carvão, a quantidade de carvão alimentada foi reduzida para manter a mesma taxa de produção de vapor na unidade. A adição de plástico não teve efeito algum na quantidade de metais pesados no gás ou cinzas da unidade. A emissão de $\mathrm{SO}_{2}$ da unidade diminuiu quando utilizada a co-combustão, visto que o plástico, ao contrário do carvão, não contém enxofre [6].

Apesar de todas as vantagens apresentadas, pesquisas anteriores mostraram que a combustão direta de grânulos ou pedaços de plástico pode liberar material particulado na atmosfera $[16,17,18]$, como mostrado na seqüência da Figura 3 , em que um copo comum de PS expandido sofre a combustão. Observa-se que a fumaça preta se espalha na atmosfera e deixa uma mancha ao final da combustão. Esta mancha preta são as partículas de fuligem maiores depositadas na base de apoio.

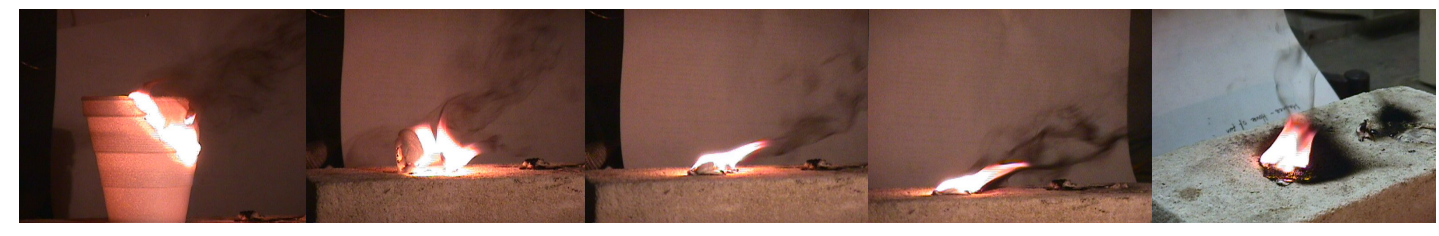

Figura 3 - Seqüência da queima de um copo de PS expandido.

Para aproveitar a energia dos resíduos plásticos por meio da combustão, e emitir menores quantidades de gases poluentes e de material particulado (os chamados produtos de combustão incompleta - PIC), é possível pirolisar o resíduo plástico e em seguida misturar o gás efluente com ar, para somente então realizar a combustão (indireta) do plástico. A combustão do gás de pirólise é chamada de combustão indireta, e pode ser uma alternativa de recuperação da energia do 
material com menos emissão de PIC, como proposto por Panagiotou et al. [19] em 1996.

Neste trabalho o estudo será focado no PE, o plástico mais encontrado nos resíduos sólidos urbanos, e o PS, que apesar de ser $04^{\circ}$ material mais consumido, tem um anel aromático na sua estrutura que favorece a formação dos PIC.

Um importante estudo foi realizado por Jinno e seus colaboradores [3]. Eles mediram o calor de pirólise do PE $(0,25 \mathrm{MJ} / \mathrm{kg})$ e do PS $(1,39 \mathrm{MJ} / \mathrm{kg})$, e observaram que esse valor é praticamente independente da taxa de aquecimento. Ao se comparar o calor de pirólise com o conteúdo energético, que são 46,3 MJ/kg para PE e 40,2 MJ/kg para PS, evidencia-se que menos de $1 \%$ do calor liberado durante a combustão do PE é requerido como entrada em um pirolisador para gaseificar este combustível e menos de 4\% para o PS. Estes dados ilustram que uma corrente gasosa de combustível pode ser produzida a partir de resíduos pela implantação de uma integração energética favorável. Apenas uma fração de energia é penalizada ao operar um pirolisador antes do incinerador, mesmo se acrescentadas as perdas inerentes ao processo.

A seguir, serão apresentados os conceitos básicos necessários para compreender os fenômenos da pirólise e combustão que ocorrem na queima dos resíduos plásticos, para que se possa controlar melhor os parâmetros das reações.

\subsection{Pirólise}

Todo processo de queima de combustíveis sólidos é precedido pelo processo denominado pirólise. A pirólise, também conhecido como destilação destrutiva, é um processo de quebra das ligações químicas das cadeias orgânicas pelo calor [20]. Neste processo, os produtos podem ser gases, líquidos e ceras, dependendo do material e da temperatura submetida.

Em geral, a pirólise é controlada pela taxa de aquecimento do material. Os fatores que interferem no processo de pirólise são o tamanho da partícula, a velocidade do gás, e o tempo de pirólise [21]. 


\subsubsection{Pirólise dos polímeros PE e PS}

Macromoléculas orgânicas são estáveis apenas abaixo de certa temperatura limite, normalmente variando de 100 a $200^{\circ} \mathrm{C}$. Os polímeros por serem formados a partir de macromoléculas orgânicas, decompõem-se em fragmentos (radicais livres, íons livres, $\mathrm{H}_{2}, \mathrm{CO}$ ) quando submetidos a temperaturas ao redor de $1000^{\circ} \mathrm{C}$ [20].

Alguns polímeros podem ser parcialmente convertidos a seus monômeros precursores pelo tratamento térmico pirolítico. Por exemplo, o PS pode ser aquecido e a maior parte dividida em sua estrutura monomérica original, o estireno. Diferente do PS, o PE e o PP produzem apenas parte deu seus monômeros originais, produzindo também hidrocarbonetos leves na forma de gás.

O PS começa sua decomposição na temperatura de $364^{\circ} \mathrm{C}$. Foi mostrado que a pirólise do PS na faixa de temperatura de $532-708^{\circ} \mathrm{C}$ produz um líquido, constituído de aproximadamente $75 \%$ de estireno, junto com outros hidrocarbonetos policíclicos aromáticos (PAH) (cerca de $10 \%$ de tolueno, etilbenzeno, propenilbenzeno, propinilbenzeno e naftaleno), com baixa produção de gases (ao redor de 15\%) e sem a formação de cinzas [22,23,24]. Outros grupos de pesquisa também pirolisaram o PS na faixa de temperatura de $360-410^{\circ} \mathrm{C}$ e a $520^{\circ} \mathrm{C}$ e obtiveram como produtos principais o monômero estireno, dímeros e trímeros [25, 26].

Os polietilenos de alta e de baixa densidade iniciam sua decomposição a $290^{\circ} \mathrm{C}$ pela quebra das ligações fracas e progressivamente pela quebra das ligações terciárias de carbono [27]. Pouca perda de peso é observada antes de alcançar a temperatura de $370^{\circ} \mathrm{C}$. Os principais produtos de sua decomposição são: um produto de óleos e ceras formados principalmente por alquenos, alquinos e alcadienos, com quase nenhuma cinza [27, 23]. Eteno e etileno são apenas alguns dos muito constituintes dos voláteis primários.

Durante a pirólise do PE de alta densidade (PEAD) na temperatura de $800^{\circ} \mathrm{C}$, este sofreu uma conversão igual a 2,5\% em massa de uma mistura de óleos e ceras, e $97,5 \%$ em massa de seu polímero foi convertido para gás, tendo a seguinte composição: $7,37 \%$ de metano, $4,54 \%$ de etano, $35,7 \%$ de etileno, $1,58 \%$ de propano, 25,7\% de propileno, 0,02\% de acetileno, 8,9\% de butileno, 0,45\% de butano, $9,17 \%$ de pentano, 3,36\% de benzeno $0,65 \%$ de tolueno e $0,1 \%$ de xileno e estirenos [31]. Da mesma maneira, outros pesquisadores converteram $96 \%$ e $80 \%$ 
do polímero para uma mistura gasosa, nas temperaturas de $810^{\circ} \mathrm{C}$ [28] e $650^{\circ} \mathrm{C}$ [29], respectivamente. As composições variaram conforme a temperatura.

Nos estudos de Ballice et al. [30] a máxima produção de voláteis na pirólise de PEBD e PEAD foi encontrada nas temperaturas de 425 e $430^{\circ} \mathrm{C}$, respectivamente. Foram identificados alquenos de cadeia linear e ramificados, alcanos de $\mathrm{C}_{1}-\mathrm{C}_{30}$ e alguns aromáticos. A porção de alcanos foi maior que alquenos em todas as temperaturas estudadas. Os óleos eram compostos principalmente de $\mathrm{C}_{10}-\mathrm{C}_{16}+$ com pequena porção de $\mathrm{C}_{5}-\mathrm{C}_{9}$.

No trabalho de Conesa et al. [31, 32] foram examinados os efeitos do tipo de polietileno, os efeitos da ramificação do polímero, comparados o sistema de pirólise em batelada e contínuo, e a influência da taxa de aquecimento na formação dos produtos da pirólise. O PE mais ramificado apresentou menor quantidade de gás nos produtos e com uma maior quantidade de produtos aromáticos, na temperatura de $800^{\circ} \mathrm{C}$. Estes resultados estão de acordo com o encontrado por Scott et al. [22] e Kaminsky [29].

O tipo de PE pirolisado, isto é, de baixa ou alta densidade, na temperatura de $800^{\circ} \mathrm{C}$, não influenciam no espectro de compostos produzidos [28,30], porém, o PEAD pode ser mais difícil de degradar que o PEBD.

O efeito do tempo de residência e a temperatura de pirólise na distribuição dos produtos de pirólise do PE foram estudados por Mastral et al. [33] em dois reatores verticais de queda livre colocados em série. Seus ensaios mostraram que até a temperatura de $700^{\circ} \mathrm{C}$ os principais produtos obtidos foram ceras e óleos; a quantidade de gás produzido aumentou conforme a temperatura aumentou. $A$ produção de aromáticos começou a ser significante a $800^{\circ} \mathrm{C}$, e mostrou uma tendência de crescimento com a temperatura e com o tempo de residência. Os principais compostos na fração gasosa foram o hidrogênio, metano e acetileno nas temperaturas até $1000^{\circ} \mathrm{C}$. Maiores tempos de residência levaram a uma quebra mais intensiva das frações alifáticas, e as emissões de metano e etileno cresceram significativamente.

Nos estudos de emissão de PAH foi mostrado que as emissões de PAH na pirólise de PE e PS são sensíveis à taxa de inserção de partículas no forno ( massa $_{\text {polímero/massa }}$ ( $\mathrm{N}_{2}$ ), e quanto maior essa taxa, maior a quantidade de $\mathrm{PAH}$ emitida [2]. A massa total de PAH produzida na combustão de PS foi mais de três vezes maior que na combustão de PS [19]. 


\subsection{Combustão}

Uma reação química em que um combustível é oxidado e uma grande quantidade de energia é liberada é chamada de combustão [34]. Qualquer material que possa ser queimado e libera energia é chamado de combustível. O oxidante mais usado é o ar e o combustível normalmente consiste primariamente de hidrogênio e carbono (exemplo: carvão, gasolina, gás natural ou plástico), e a reação acontece segundo o esquema:

$\mathrm{C}_{a} \mathrm{H}_{b} \mathrm{O}_{c}+\left(a+\frac{b}{4}-\frac{c}{2}\right)\left(\mathrm{O}_{2}+3,76 N_{2}\right) \rightarrow a \mathrm{CO}_{2}+\frac{b}{2} \mathrm{H}_{2} \mathrm{O}+3,76\left(a+\frac{b}{4}-\frac{c}{2}\right) N_{2} \quad$ Equação 1

Ar seco pode ser aproximado como $21 \%$ de oxigênio e $79 \%$ de nitrogênio. Assim, cada mol de oxigênio entrando em uma câmara de combustão irá ser acompanhado por $0,79 / 0,21=3,76$ moles de nitrogênio. Em condições normais de temperatura de combustão, o nitrogênio se comporta como inerte e não reage com outros compostos químicos. Mas em temperaturas ao redor de $1000^{\circ} \mathrm{C}$, uma pequena parte do nitrogênio reage com o oxigênio, formando gases perigosos, como o óxido nítrico.

$\mathrm{O}$ ar que entra na combustão normalmente contém algum vapor de água, que também merece consideração quando em altas temperaturas, pois alguma parte pode se dissociar em $\mathrm{H}_{2}, \mathrm{O}_{2}, \mathrm{H}, \mathrm{O}$ e OH .

O combustível precisa estar em contato íntimo com oxigênio e sua temperatura elevada acima da temperatura de ignição para começar a combustão. Ainda mais, a proporção de combustível e ar precisa estar na faixa do limite de inflamabilidade para a combustão iniciar.

A razão de combustível-ar (CA) é a razão da massa de combustível ( $\left.m_{\text {combustivel }}\right)$ para a massa de ar $\left(m_{a r}\right)$ num processo de combustão.

$\mathrm{CA}=\mathrm{m}_{\text {combustive }} / \mathrm{m}_{\mathrm{ar}}$

Equação 2

Em situações reais de combustão, é uma pratica comum utilizar mais ar do que a quantidade estequiométrica, para melhorar as chances da combustão completa ou para controlar a temperatura da combustão. A medida utilizada para expressar a quantidade de ar usada é a razão equivalente $(\phi)$ que pode ser definida 
como a razão verdadeira de ar e combustível em relação à razão estequiométrica de ar e combustível (Equação 3).

$$
\phi=\frac{C A_{\text {real }}}{C A_{\text {estequiometrico }}}=\frac{\left(\frac{m_{\text {combustivel }}}{m_{a r}}\right)_{\text {real }}}{\left(\frac{m_{\text {combustivel }}}{m_{\text {ar }}}\right)_{\text {estequiometrico }}}
$$

Equação 3

Quando é realizada a combustão em condições pobres em combustível, e portanto, ricas em ar, $\phi<1$, ocorre a presença de oxigênio entre os produtos da combustão (excesso), e a reação de combustão passa a ser:

$$
\begin{aligned}
& \mathrm{C}_{a} \mathrm{H}_{b} \mathrm{O}_{c}+\frac{1}{\phi}\left(a+\frac{b}{4}-\frac{c}{2}\right)\left(\mathrm{O}_{2}+3,76 N_{2}\right) \rightarrow \\
& a \mathrm{CO}_{2}+\frac{b}{2} \mathrm{H}_{2} \mathrm{O}+\left(\frac{1}{\phi}-1\right)\left(a+\frac{b}{4}-\frac{c}{2}\right) O_{2}+\frac{3,76}{\phi}\left(a+\frac{b}{4}-\frac{c}{2}\right) N_{2}
\end{aligned}
$$

Equação 4

Quando é realizada a combustão em condições ricas em combustível, e portanto, pobres em ar, $\phi>1$, os produtos de reação incompleta $\mathrm{CO}$ e $\mathrm{H}_{2}$ e passam a fazer parte do segundo termo da reação de combustão, que pode ser simplificada para:

$$
\begin{aligned}
& \mathrm{C}_{a} \mathrm{H}_{b} \mathrm{O}_{c}+\frac{1}{\phi}\left(a+\frac{b}{4}-\frac{c}{2}\right)\left(\mathrm{O}_{2}+3,76 \mathrm{~N}_{2}\right) \rightarrow \\
& (a-x) \mathrm{CO}_{2}+x \mathrm{CO}+\left(\frac{b}{2}-\frac{x}{2}\right) \mathrm{H}_{2} \mathrm{O}+\frac{x}{2} \mathrm{H}_{2}+\frac{3,76}{\phi}\left(a+\frac{b}{4}-\frac{c}{2}\right) N_{2}
\end{aligned}
$$

Equação 5

Um processo real de combustão dificilmente ocorre de forma completa, mesmo na presença de excesso de oxigênio. Assim, prever a composição dos produtos da combustão incompleta não é algo simples, e algumas simplificações são necessárias, como desconsiderar na equação de formação dos produtos a fuligem e os hidrocarbonetos.

Em um processo de batelada é comum estimar uma razão equivalente média ( $\left.\phi_{\text {médio }}\right)$ que representa a reação ao longo do tempo e do forno, já que as condições são transientes. Para fornos de fluxo contínuo é possível estabelecer a razão 
equivalente correta, pois depois de estável o sistema, todos os parâmetros são constantes.

A quantidade mínima de ar necessária para a queima completa de um combustível é chamada de ar teórico ou estequiométrico em uma combustão teórica ou estequiométrica.

O processo de combustão com menos da quantidade de ar teórica, $\phi<1$, está fadado a ser incompleto, e ocorre quando [34]:

- Há oxigênio insuficiente;

- Não há mistura suficiente do combustível com o comburente na câmara de combustão durante o limitado tempo em que os elementos estão em contato;

- A temperatura do forno não é mantida constante, homogênea no combustível e elevada o suficiente para garantir a total degradação dos compostos orgânicos. De uma forma geral o tempo de residência diminui com o aumento da temperatura. Não basta apenas trabalhar com temperatura elevada, é preciso que haja homogeneidade de temperatura no reator para se garantir o tempo de residência naquela faixa de temperatura;

- Os resíduos não permanecem na região de alta temperatura por tempo suficiente para a sua total combustão e/ou decomposição, e para evitar isso deve-se observar a cinética de oxidação dos compostos. A permanência dos compostos a altas temperaturas em tempos insuficientes provoca a formação dos PIC;

- Ocorre dissociação dos compostos presentes, que passa a ser importante em altas temperaturas. As reações de dissociação recorrentes nos processos de combustão são [35]:

$$
\begin{array}{ll}
2 \mathrm{CO}_{2} \leftrightarrow 2 \mathrm{CO}+\mathrm{O}_{2} & \text { Equação 6 } \\
2 \mathrm{H}_{2} \mathrm{O} \leftrightarrow 2 \mathrm{H}_{2}+\mathrm{O}_{2} & \text { Equação 7 }
\end{array}
$$

Outros constituintes como $\mathrm{N}, \mathrm{O}, \mathrm{H}, \mathrm{OH}, \mathrm{NO}$ e $\mathrm{C}$, podem ser formados por outras dissociações e combinação de vários constituintes.

\subsubsection{Chamas}

No processo de combustão, chamas são criadas por uma reação de autopropagação exotérmica que usualmente apresenta uma zona de reação 
luminosa associada a ela. Os tipos de chamas existentes são dependentes das limitações físicas da mistura do combustível com o oxidante, e caracterizam o tipo de combustão por serem pré-misturadas ou difusas.

As chamas pré-misturadas podem ser turbulentas e laminares. Exemplos de chamas pré-misturadas turbulentas: motor a gasolina e turbina a gás estacionária com baixo NOx. Exemplos de chamas pré-misturadas laminares: chama flat e bico de bunsen (Figura 4a).

As vantagens da combustão pré-misturada são: maior controle em condições pobres em combustível, evita o uso desnecessário de altas temperaturas, menor produção de NO e fuligem em relação a chamas difusas [36].

As chamas difusas, também chamadas de não pré-misturadas, podem ser do tipo co-corrente ou contracorrente e ainda turbulentas ou laminares. São usadas em fornos industriais e queimadores. Este tipo de chama apresenta luminescência amarelada, o que caracteriza condições para a formação de fuligem.

$\mathrm{Na}$ chama difusa, a reação de combustão deve aguardar a chegada do oxidante, fato que não ocorre na chama pré-misturada, pois o combustível e oxidante já estão misturados. Etapas preparatórias como a pirólise, devolatilização, evaporação, ou quebra térmica podem acontecer nas redondezas da chama pela influência de calor radioativo. Exemplos de chamas difusas turbulentas: combustão em fornos de batelada, combustão de carvão pulverizado, turbina de avião, motor a diesel e motor de foguete de $\mathrm{H}_{2} / \mathrm{O}_{2}$. Exemplos de chamas difusas laminares: fogueira com madeira, e vela (Figura 4b).

a)

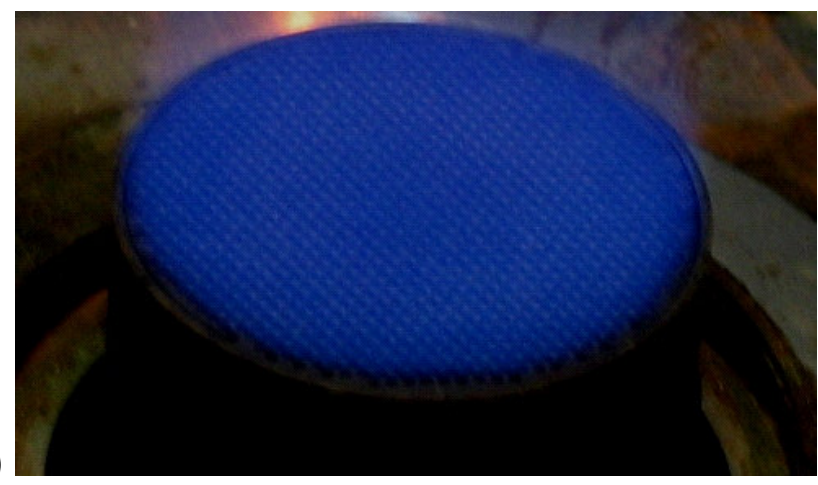

b)

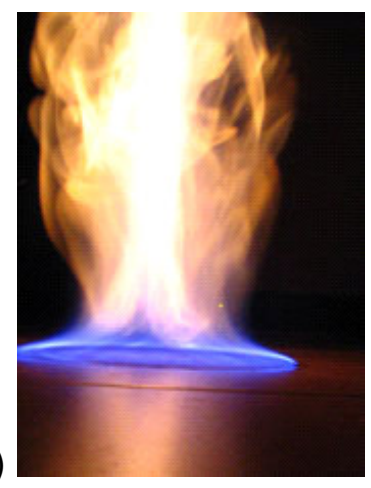

Figura 4 - a) Chama pré-misturada e b) Chama difusa. 


\subsubsection{Produtos de combustão incompleta}

Um processo de combustão é completo se todo o carbono no combustível queima para $\mathrm{CO}_{2}$, todo o hidrogênio para $\mathrm{H}_{2} \mathrm{O}$, e todo o enxofre (se existir algum) queimar para $\mathrm{SO}_{2}$. Por conseguinte, um processo de combustão é incompleto se os produtos de combustão contêm algum combustível não queimado (chamados PIC produtos de combustão incompleta) como carbono, fuligem e gases (como hidrocarbonetos policíclicos aromáticos, hidrocarbonetos leves, $\mathrm{H}_{2}, \mathrm{CO}$ ou OH) [37].

\subsubsection{CO}

A formação do monóxido de carbono é uma das principais etapas de reação no mecanismo de combustão dos hidrocarbonetos, que pode ser resumida em [38]:

$$
\mathrm{R}-\mathrm{H} \rightarrow \mathrm{R}-\rightarrow \mathrm{R}-\mathrm{O}_{2} \rightarrow \mathrm{R}-\mathrm{CHO} \rightarrow \mathrm{R}-\mathrm{CO} \rightarrow \mathrm{CO}
$$

Equação 8

onde $\mathrm{R}$ é o radical do hidrocarboneto.

$\mathrm{O} \mathrm{CO}$ formado no processo de combustão por esta via é então oxidado a $\mathrm{CO}_{2}$ em uma taxa menor. A principal reação de oxidação do CO nas chamas de hidrocarboneto-ar é [38]:

$$
\mathrm{CO}+\mathrm{OH}^{-} \rightarrow \mathrm{CO}_{2}+\mathrm{H}^{+}
$$

Equação 9

\subsubsection{Emissões orgânicas gasosas}

Os hidrocarbonetos são conseqüências da combustão incompleta de combustíveis de hidrocarbonetos. As emissões aumentam rapidamente conforme a mistura se torna mais rica em $\mathrm{O}_{2}$.

Enquanto a emissão total de hidrocarbonetos é uma medida útil da ineficiência da combustão, não é necessariamente um índice significativo das emissões poluentes. Alguns desses hidrocarbonetos são praticamente inertes fisiologicamente e não reativos do ponto de vista da poluição fotoquímica (smog), como os alcanos de 1 a 4 carbonos alifáticos e cíclicos, o benzeno e o acetileno. Porém, outros hidrocarbonetos são produtos químicos altamente reativos, como os alcenos com substituições na ligação dupla e cicloolefinas [38].

A composição do combustível pode influenciar significativamente na composição e magnitude das emissões orgânicas. Combustíveis que contêm mais 
aromáticos e olefinas produzem maiores concentrações de hidrocarbonetos reativos do que os combustíveis alifáticos. Ainda, muitos dos compostos orgânicos encontrados no efluente não estão presentes no combustível, indicando que há ocorrência de pirólise e sínteses durante o processo de combustão [38].

Uma classe importante dos hidrocarbonetos é a dos policíclicos aromáticos, $\mathrm{PAH}$, em que dois ou mais anéis aromáticos são acoplados. O menor PAH existente é o naftaleno $\left(\mathrm{C}_{10} \mathrm{H}_{8}\right)$. Os PAH possuem baixa pressão de vapor e, portanto, podem existir na forma gasosa ou adsorvidos em partículas. São insolúveis em água e dissolvem-se em gasolinas e óleos. Sua formação ocorre na combustão incompleta de compostos orgânicos de alta massa molecular, e é favorecida em condições de baixa concentração de oxigênio e nas temperaturas de 650 a $900^{\circ} \mathrm{C}$ [20].

Embora a maior parte dos PAH não mostre atividades mutagênicas, alguns são carcinogênicos, como o benzo(a)pireno, e um grande número deles foram descobertos como causadores de mutações em células humanas e de bactérias. A formação de $\mathrm{PAH}$ e material particulado não está necessariamente ligada, pois é possível produzir PAH sem produzir a fuligem. Porém os PAH são facilmente encontrados na fuligem, pois estes condensam no sólido em temperaturas menores que $200^{\circ} \mathrm{C}$ [39].

As possíveis origens da formação dos $\mathrm{PAH}$ podem ser combustíveis não oxidados; combustíveis que sofreram pirólise, mas não passaram por uma zona de chama; ou ainda, o PAH pode ser produzido na chama. O combustível vaporizado, e misturado com os produtos quentes da combustão podem pirolisar e oxidar, e estas misturas podem passar direto pela zona de combustão e fazer parte do efluente do gás de exaustão. Nestas circunstâncias os combustíveis aromáticos podem ser parcialmente oxidados. Em temperaturas altas, a síntese do PAH e da fuligem a partir dos fragmentos do combustível tem mais chances de ocorrer [39].

A formação do primeiro anel aromático de pequenas moléculas alifáticas tem sido considerada a etapa limitante na taxa de formação de moléculas maiores. Os mecanismos mais aceitos são: adição de acetileno ao n- $\mathrm{C}_{4} \mathrm{H}_{3}$ e $\mathrm{n}^{-} \mathrm{C}_{4} \mathrm{H}_{5}$; combinação de radicais propargil $\left(\mathrm{C}_{3} \mathrm{H}_{3}\right)$; adição de moléculas de carbono em número impar $\left(\mathrm{C}_{5} \mathrm{H}_{5}+\mathrm{CH}_{3}\right.$ ou $\left.\mathrm{C}_{5} \mathrm{H}_{5}+\mathrm{C}_{5} \mathrm{H}_{5}\right)$; e a reação de propargil e acetileno para formar um radical ciclopentadienil $\left(\mathrm{c}-\mathrm{C}_{5} \mathrm{H}_{5}\right)$, que reage rapidamente para formar benzeno [40].

$O$ processo de crescimento das pequenas moléculas como o benzeno, para cada vez maiores PAH envolve a adição de $C_{2}, C_{3}$, e outras moléculas pequenas 
(dentre as quais o acetileno) a radicais de $\mathrm{PAH}$, e reações entre espécies aromáticas, como $\mathrm{PAH}-\mathrm{PAH}$, recombinação de radicais e reações de adição. $\mathrm{O}$ acetileno tem recebido grande atenção dos pesquisadores pela importância do mecanismo de crescimentos dos $\mathrm{PAH}$ na abstração- $\mathrm{H}$-adição- $\mathrm{C}_{2} \mathrm{H}_{2}$ (HACA $-\mathrm{H}$ abstraction $\mathrm{C}_{2} \mathrm{H}_{2}$-addition) $[41,40]$.

Dos vários mecanismos de formação dos $\mathrm{PAH}$, nenhum foi estabelecido como único, e os mecanismos iônico e radical podem acontecer ao mesmo tempo, dependendo do tipo de chama, temperatura e combustível analisados [39]. No caso de combustíveis aromáticos (como o benzeno), os reagentes ativos (como o acetileno) que participam na formação dos aromáticos são formados em relativamente grandes concentrações na quebra do combustível. No caso de combustíveis alifáticos, como o acetileno, o etileno e o metano, o primeiro anel aromático precisa ser formado a partir dos produtos de decomposição do combustível, por uma seqüência de reações elementares, em que a formação do anel ativo reagente está em menor concentração que nas chamas aromáticas [41].

\subsubsection{Material Particulado}

Material particulado é o termo utilizado para uma mistura de partículas sólidas e gotas de líquidos encontrados na atmosfera. Algumas destas partículas podem ser grandes e escuras e, portanto, visíveis como fumaça ou fuligem. Outras são tão pequenas que somente podem ser vistas através de um microscópio. O material particulado tem como origem fontes naturais e fontes artificiais. Dentre as fontes naturais pode-se citar as poeiras espalhadas pelo vento, e como fontes artificiais tem-se os motores de veículos, as caldeiras industriais ou a fumaça do cigarro [42].

As partículas de fuligem podem aquecer a atmosfera diretamente pela absorção de luz e indiretamente pela formação de nuvens. Em razão deste aquecimento, alguns cientistas argumentam que reduzir a emissão de fuligem é uma estratégia melhor para conter o aquecimento global do que reduzir as emissões de $\mathrm{CO}_{2}$. Numerosos estudos epidemiológicos na década passada, nos Estados Unidos e Europa, sugerem que a exposição às partículas finas $(<2,5 \mu \mathrm{m})$ aumenta a mortalidade por doenças do coração e pulmonares [43].

O material particulado pode ser formado de partículas inorgânicas, como as cinzas, e partículas orgânicas, como a fuligem. Na combustão em altas temperaturas e baixa concentração de $\mathrm{O}_{2}$, forma-se a fuligem [21]. É suposto que as moléculas 
precursoras da fuligem são PAH com peso molecular entre 500 e 1000 unidades de massa atômica (amu). A formação da fuligem é um processo complexo que envolve muitas etapas físicas e químicas. A Figura 5 resume essas etapas [43].

Como citado, a decomposição do combustível pode acontecer pelo processo de pirólise; a formação e crescimento dos aromáticos acontecem pela reação de pequenas moléculas formando o primeiro anel aromático, e por seguinte, a adição de outras moléculas, radicais ou até mesmo outros anéis aromáticos para formar maiores $\mathrm{PAH}$.

A transição das espécies da fase gasosas para a partícula sólida é provavelmente a parte menos compreendida do processo de formação da fuligem. Um dos modelos mais aceitos é a acumulação de massa via reações químicas com precursores gasosos (pela assimilação de pequenas moléculas e PAH pelas margens e superfície), simultaneamente com o crescimento do tamanho da partícula pela colisão e agrupamento de espécies de moléculas de PAH [40].

Uma vez que as partículas são formadas, elas colidem umas com as outras formando partículas maiores. Estudos experimentais observaram que inicialmente a partícula parece esférica, e depois adquire um formato irregular [40].

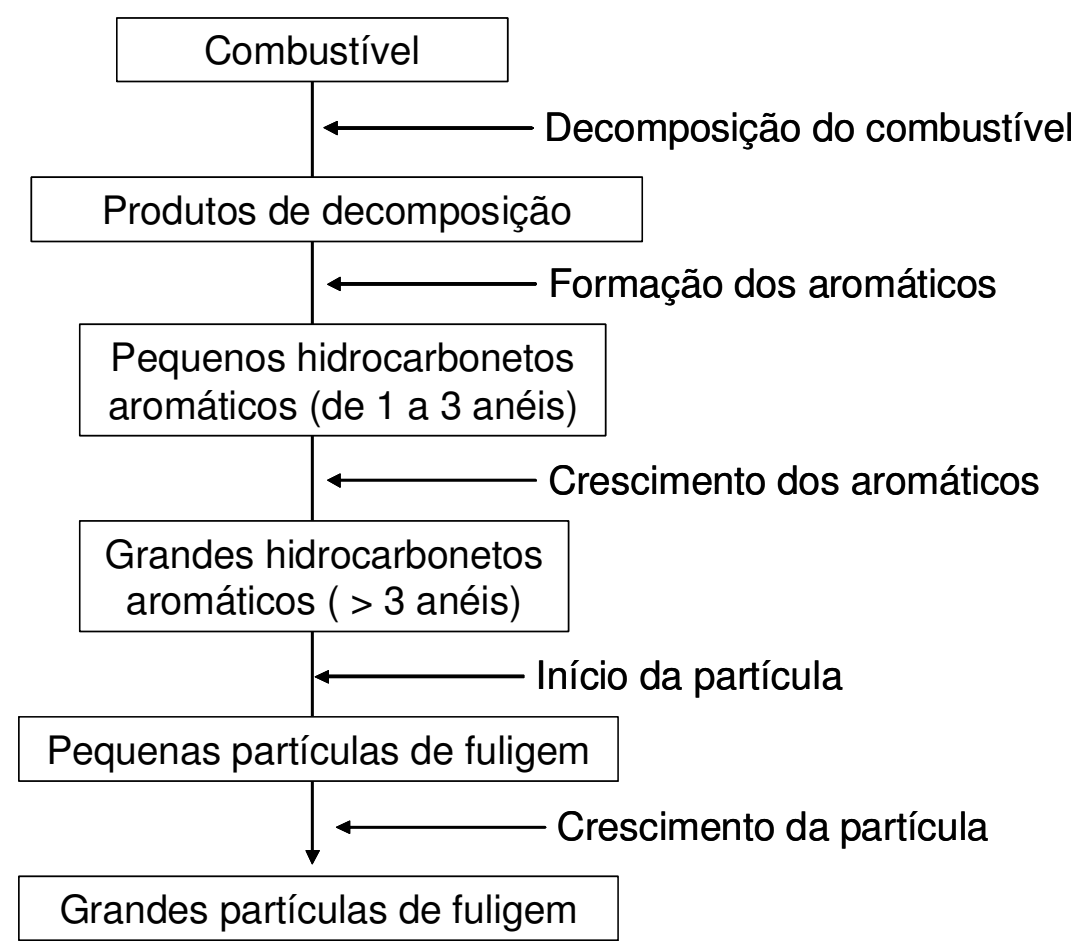

Figura 5 - Etapas da formação das partículas de fuligem. 


\subsubsection{Combustão dos polímeros PE e PS}

O PE apresenta a formula $\left(\mathrm{C}_{2} \mathrm{H}_{4}\right)_{n}$, e o PS $\left(\mathrm{C}_{8} \mathrm{H}_{8}\right)_{n}$. A partir das equações 1,4 e 5 é possível calcular as emissões de $\mathrm{CO}, \mathrm{CO}_{2}, \mathrm{H}_{2} \mathrm{O}$ e $\mathrm{H}_{2}$ em função da razão equivalente $(\phi)$ usada para cada combustível. Portanto, mesmo que não seja usado o valor estequiométrico na combustão, é possível verificar se os dados experimentais estão próximos dos valores teóricos [44], como apresentado na Figura 6 para o PE, e na Figura 7 para o PS.

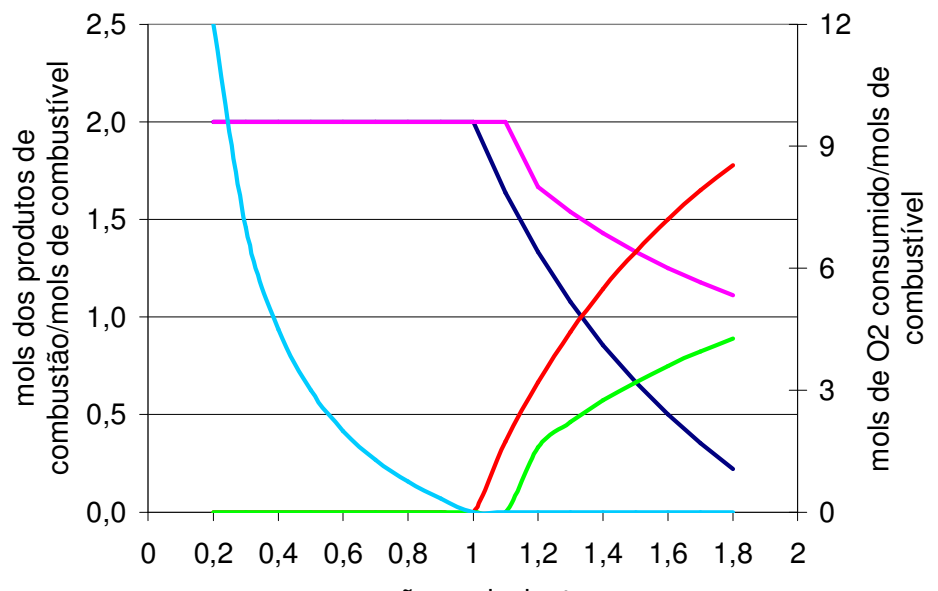

- mols $\mathrm{CO} 2$ - mols $\mathrm{H} 2 \mathrm{O}$ - mols $\mathrm{CO}$ - mols $\mathrm{H} 2$ - mols $\mathrm{O} 2$

Figura 6 - Emissões teóricas dos produtos de combustão de PE.

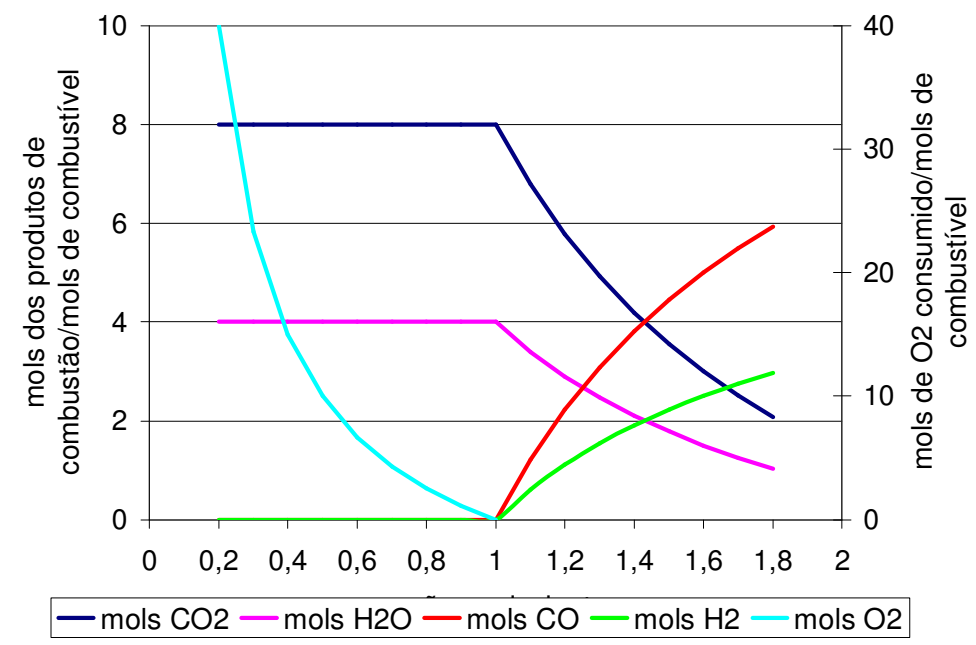

Figura 7 - Emissões teóricas dos produtos de combustão de PS.

Investigações dos produtos das reações de combustão de polímeros têm sido realizadas há décadas em diversos países. Vários estudos implantaram a 
combustão direta de partículas de PE e PS, nos quais o polímero sólido queimou com chamas difusas ou pré-misturadas. As emissões de $\mathrm{CO}_{2}, \mathrm{CO}$, hidrocarbonetos leves $(\mathrm{HL}), \mathrm{PAH}$ e materiais particulados foram examinados. Para tanto, esforços para minimizar as emissões poluentes foram realizados usando diferentes condições como a combustão com estágios, alteração da temperatura do forno e da taxa de alimentação dos polímeros, instalação de um pós-queimador e emprego de um filtro cerâmico de alta temperatura. As condições que minimizam os PIC foram identificadas.

As técnicas usadas nas pesquisas podem ser divididas em:

- Combustão em batelada;

- Combustão em sistema contínuo;

- Combustão em estado estacionário unidimensional.

\subsubsection{Combustão em batelada}

Na combustão em batelada o combustível queima de forma transiente, na presença de chamas difusas, em que a razão equivalente é apenas um valor médio das condições ao longo do tempo e do forno.

A cinética de pirólise e combustão de PEAD foi estudada por Font et al. [45]. Eles observaram que durante a combustão na temperatura mais alta, a produção de $\mathrm{CO}$ e $\mathrm{CO}_{2}$ diminuiu, e que menores quantidades de $\mathrm{O}_{2}$ aumentaram a produção de $\mathrm{CO}$ e $\mathrm{CO}_{2}$. A produção de hidrocarbonetos leves de 3 a 6 carbonos na estrutura diminuiu com o aumento da temperatura, enquanto o metano, o etano, o etileno, o benzeno e o tolueno tiveram tendência contrária, isto é, aumentaram com o aumento da temperatura. A quantidade de compostos semivoláteis (tanto alifáticos quanto aromáticos) diminuiu com a diminuição da razão equivalente $\phi_{\text {médio. }} \mathrm{A}$ presença de oxigênio, muito provavelmente, facilita a formação de radicais, contribuindo para uma situação mais reativa.

Diversos trabalhos foram realizados no forno horizontal do laboratório da Northeastern University (NU) na ultima década para a combustão de estireno líquido e partículas e pellets de PE e PS [15, 18, 46, 47, 48]. Bateladas de estireno líquido foram queimadas, pois o monômero de estireno é o produto de degradação do PS emitido em maior quantidade. O esquema do forno utilizado está apresentado na Figura 8. 


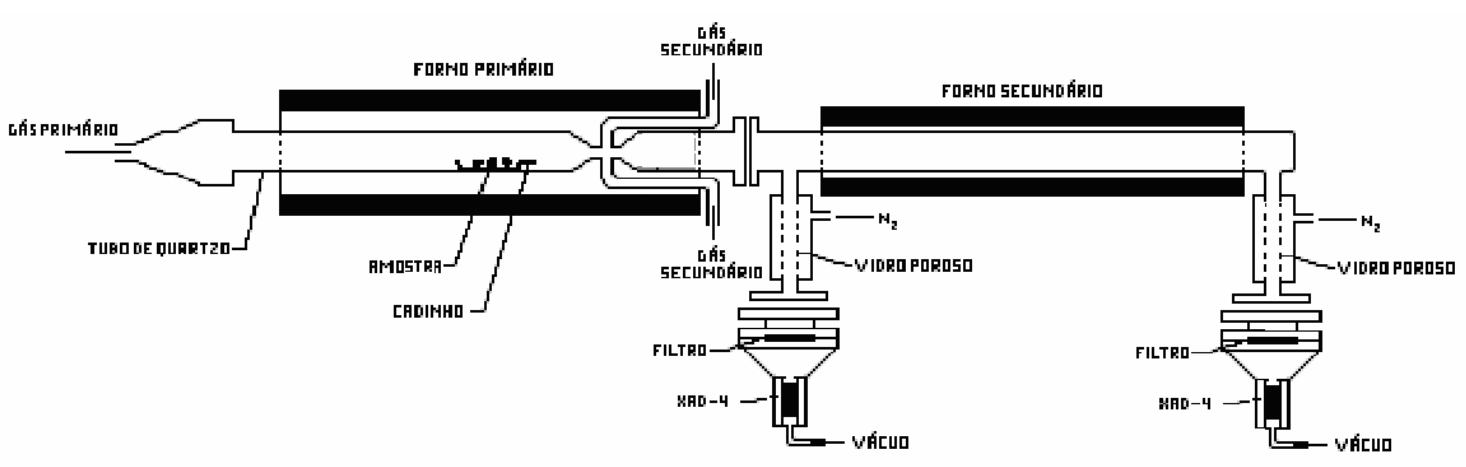

Figura 8 - Esquema do forno utilizado em diversos estudos na NU.

Fonte: adaptado pelo autor [20]

As principais conclusões obtidas foram:

- para o PE, o PS e o estireno: quando a temperatura do forno primário aumentou acima de $600^{\circ} \mathrm{C}$, a quantidade de $\mathrm{CO}_{2}$ emitida diminuiu.

- para o PS: a quantidade de CO não mudou significativamente quando a temperatura no primeiro estágio aumentou. No caso do PE, o aumento foi mais significativo quando a razão equivalente no forno foi menor. Na combustão do estireno, o aumento da temperatura no primeiro forno não alterou a emissão de CO no primeiro estágio, porém, diminuiu 10 vezes no pós-queimador.

- o pós-combustor aumentou as concentrações de $\mathrm{CO}$ e $\mathrm{CO}_{2}$ nas temperaturas acima de $700^{\circ} \mathrm{C}$, tanto para o PE quanto para o PS e o estireno.

- a variação de temperatura de 900 a $1100^{\circ} \mathrm{C}$ no pós-queimador não alterou as emissões de $\mathrm{CO}$ e $\mathrm{CO}_{2}$ na combustão do PS.

- para todos os compostos estudados, o aumento da temperatura no forno primário aumentou as emissões totais de PAH no primeiro forno e no pós-queimador. $\mathrm{O}$ aumento da temperatura no forno secundário diminuiu as emissões totais de PAH do PS.

- na combustão de PS a emissão de PAH total no forno primário foi maior do que no pós-queimador. Na combustão do $\mathrm{PE}$ e do estireno, em razões equivalentes altas, a concentração de PAH no forno secundário algumas vezes foi maior do que no forno primário (nas temperaturas mais altas).

- para o PS, as emissões de particulados do pós-queimador foram menores que a emissão do primeiro forno, quando variada a temperatura do primeiro e do 
segundo forno, na ausência de filtros cerâmicos. No geral, a produção de material particulado aumentou com o aumento da temperatura no forno primário. O aumento da temperatura no forno secundário aumentou a emissão de particulados. O filtro cerâmico na saída do primeiro forno não alterou a produção final de particulados, isto é, no pós-queimador. Porém, a utilização do filtro no pós-queimador diminuiu drasticamente a emissão de particulados.

- para o PE, o aumento da temperatura no forno primário não alterou a produção de particulados, porém aumentou a produção no forno secundário.

- para o estireno, o aumento da temperatura no forno primário aumentou a produção de particulados, porém praticamente não alterou a produção no forno secundário.

- para todos os compostos, nas temperaturas mais baixas as partículas coletadas tinham aspecto branco acinzentadas, sendo a maior parte produtos de pirólise. Nas temperaturas mais altas (acima de $700-800^{\circ} \mathrm{C}$ ), a cor se tornou preto (característica de formação de fuligem).

\subsubsection{Combustão em sistema contínuo}

A combustão em sistema contínuo foi estudada em fornos verticais, onde as partículas caíram livremente sofrendo a combustão ao passar pela zona quente do forno. Neste sistema o combustível queima de forma transiente, com formação de chamas difusas, e assim como na combustão em batelada a razão equivalente é apenas um valor médio das condições ao longo do forno. Porém, depois de estabilizado o sistema, os acontecimentos em cada região específica do forno não variam com o tempo.

Durante a combustão de partículas de diferentes tamanhos de PS foi mostrada uma queda exponencial no número total de espécies de PAH, e da massa total de emissões, quando a temperatura de combustão aumentou e o tamanho das partículas alimentadas diminuiu. $\mathrm{O}$ tamanho médio das partículas produzidas de fuligem aumentou com o aumento da temperatura de combustão e diminuiu com o aumento do tamanho das partículas alimentadas de polímero [49].

Um forno vertical, como esquematizado na Figura 9, situado na Northeastern University foi utilizado para vários estudos sobre a combustão de PE e PS, que 
serão apresentados a seguir. Um sistema de fluidização de partículas foi montado para que a estabilidade fosse mantida pelo maior tempo possível.

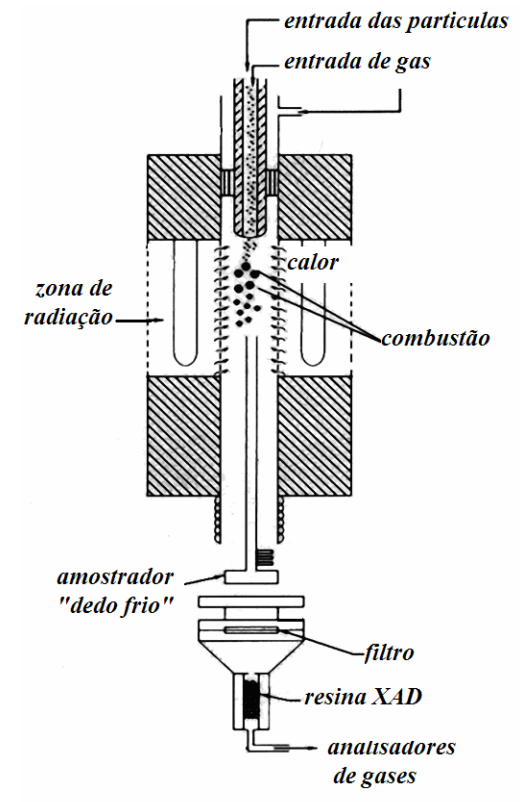

Figura 9 - Esquema do forno utilizado nos estudos de sistema contínuo na NU.

Fonte: adaptado pelo autor [51]

Foi observado nestes estudos que [17]:

- a taxa de devolatilização é determinada pela taxa de transferência de calor do polímero.

- a taxa de combustão é controlada principalmente pela temperatura da chama e pela concentração de oxigênio disponível.

- a taxa de reação de combustão das partículas de PE é governada pela taxa de pirólise.

- a taxa de combustão de partículas de PS é governada pela difusão de oxigênio.

Na combustão de PE e PS, as emissões de $\mathrm{NO}_{x}$ diminuíram drasticamente com o aumento da razão equivalente, e aumentaram com o aumento da temperatura no forno. Traços de $\mathrm{SO}_{2}$ foram detectados durante a combustão do PS. A emissão de $\mathrm{CO}_{2}$ foi proporcional à quantidade de carbono no combustível, e a pressão parcial aumentou até $\phi=1$, e depois permaneceu praticamente constante. As emissões de CO foram quase inexistentes em baixas razões equivalentes, porém as emissões aumentaram nas regiões ricas em combustível [50]. 
No produto de combustão de PE e PS, a porcentagem de naftaleno na quantidade total de $\mathrm{PAH}$ emitido foi menor quando a razão equivalente foi próxima à estequiométrica. Mostrou ainda que a quantidade total de PAH na fase condensada e gasosa aumentou com o aumento de $\phi_{\text {médio. }}$ A combustão de PS emitiu fuligem em todos os $\phi s$ estudados, enquanto o PE emitiu somente nos $\phi s$ mais altos, e em menor quantidade [2]. A emissão total de PAH foi maior na combustão de PE do que na combustão de PS [2,19].

A quantidade total emitida de particulado aumentou com a razão equivalente $(\phi)$, tanto para PE quanto para PS. Na combustão de PS, a proporção de $\mathrm{PM}_{2}$ foi maior nos $\phi$ s mais baixos. $\mathrm{A} \% \mathrm{PM}_{2}$ foi praticamente constante, sendo cerca de $35 \%$ para PS, e entre 71 - 97\% para PE [17]. A quantidade total de material particulado emitido na queima de PS foi maior do que na queima do PE. Isso ocorreu, pois o PS pirolisa mais prontamente que o PE, formando compostos de vários anéis (PAH), em condições de queima com partícula única ou em grupo de partículas. Tais PAH são eventualmente mais fáceis de formar fuligem, que é de difícil queima mesmo em condições muito pobres em combustível (com menor número de partículas).

Neste mesmo forno foram comparadas as emissões de PE e PS em situações ricas em combustível (ricas em partículas) e pobres em combustível (partículas únicas ou dispersas). Partículas únicas de PE inicialmente queimaram em chamas frias e fracas, com algumas dezenas de graus acima da temperatura do gás. Em seguida, chamas quentes surgiram onde a reação acelerou rapidamente depois da ignição. Nestas condições as emissões de PAH e fuligem foram desprezíveis. Quando partículas estavam na proximidade de outras partículas, em altos $\phi s$, um envelope de chamas cresceu maior, mais brilhante e com caudas mais longas e luminosas. Nas condições de altas razões equivalente houve a formação de fuligem [16].

Um estudo sobre o PS avaliou a evolução dos PIC ao longo da zona de reação e no final do forno de combustão [51]. A emissão de $\mathrm{CO}_{2}$ foi praticamente constante ao longo da zona de reação do forno, mas a emissão de CO aumentou. Acetileno, metano e etileno foram os hidrocarbonetos leves mais abundantes. As emissões de estireno foram maiores do que das espécies alifáticas em uma ordem de magnitude, e ainda as emissões de benzeno foram quase três vezes menores que o estireno. As espécies de $\mathrm{PAH}$ mais abundantes foram $\mathrm{O}$ naftaleno, 
fluoranteno, acenaftileno, bifenila e fenantreno. As emissões destes três últimos compostos diminuíram na zona de reação, sugerindo que as reações de consumo para estas espécies foram dominantes através da zona de reação.

\subsubsection{Fluxo contínuo em chama pré-misturada de uma dimensão}

Ali et al. estudou a combustão de etilbenzeno em um queimador de chama unidimensional (flat), em que uma chama pré-misturada foi criada [4,52]. Neste sistema, o $\phi$ apresentado não é uma média, mas o valor realmente encontrado ponto a ponto. O etilbenzeno foi estudado pois em uma chama a conversão deste composto para estireno é completa e extremamente rápida. $O$ estudo com bateladas de estireno mostrou muitas incertezas e este sistema mostrou-se mais estável e seguro para o pesquisador. Os resultados da combustão do etilbenzeno foram comparados com os resultados apresentados nas seções de Combustão de PS em sistema batelada e contínuo (apresentados acima). Os resultados mostraram que os $\mathrm{PAH}$ emitidos da combustão de etilbenzeno em $\phi=2,5$ foram menores que as emissões da combustão em sistema contínuo de PS, em batelada de PS e estireno, nesta ordem. As emissões de $\mathrm{CO}$ e $\mathrm{CO}_{2}$ foram mais elevadas na chama prémisturada do que nos sistemas de chama difusa.

Para minimizar ainda mais as emissões dos produtos de combustão incompleta, esta pesquisa tem como objetivo impedir sua formação pela implantação da combustão indireta, ao invés da combustão direta, em que as chamas difusas são criadas. Na combustão indireta os produtos de pirólise do polímero foram queimados em chama nominalmente pré-misturada. Foi suposto que neste sistema o controle das reações de formação e destruição dos produtos de combustão seria melhor e que seriam evitadas as formações dos PIC.

Consequentemente, para proporcionar a combustão indireta, os polímeros foram pirolisados, e em seguida os gases foram efetivamente misturados com uma mistura de $\mathrm{N}_{2} / \mathrm{O}_{2}$ e queimados. As emissões foram monitoradas e contrastadas com as emissões da combustão direta dos polímeros. 


\section{OBJETIVOS}

O objetivo do trabalho é a identificação dos principais produtos de pirólise e combustão indireta de PE e PS, para compreender a tendência de formação e consumo dos produtos de combustão incompleta, e por conseguinte, minimizar os impactos ambientais associados ao uso destas técnicas na recuperação da energia dos resíduos plásticos.

Para tanto, foram realizados os seguintes ensaios:

- Pirólise em fluxo contínuo de partículas de PE e PS e análise dos principais produtos (hidrocarbonetos leves e hidrocarbonetos policíclicos aromáticos).

- Combustão precedida pela pirólise de partículas de PE e PS, com análise de CO, $\mathrm{CO}_{2}$, hidrocarbonetos leves, PAH e materiais particulados. Nessa série de ensaios foram variadas a temperatura de combustão e a taxa de inserção das partículas no forno pirolisador.

- Caracterização do tamanho das partículas geradas no processo de pirólise seguida de combustão de PE e PS utilizando um separador e coletor de partículas.

Os resultados obtidos neste trabalho foram comparados com a literatura sobre pirólise e combustão direta do PE e do PS. Foram avaliadas as condições que tiveram os melhores resultados e, portanto, foram emitidas as menores quantidades de produtos de combustão incompleta. 


\section{MATERIAIS E MÉTODOS}

\subsection{Materiais}

Pó de polietileno de média densidade, PEMD $\left(-\mathrm{C}_{2} \mathrm{H}_{2^{-}}\right.$, densidade $0,94 \mathrm{~g} / \mathrm{ml}$ a $25^{\circ} \mathrm{C}$, n ${ }^{\circ} \mathrm{CAS}$ 9002-88-4) e pellets de PS $\left(-\mathrm{CH}_{2}-\mathrm{CHC}_{6} \mathrm{H}_{6}\right.$, densidade $1,04 \mathrm{~g} / \mathrm{ml} \mathrm{a}$ $25^{\circ} \mathrm{C}$, n ${ }^{\circ} \mathrm{CAS}$ 9003-53-6) da Chemical Aldrich foram usados. A amostra de PS foi moída e peneirada para manter a granulometria de $+38-125 \mu \mathrm{m}$. O pó de PEMD foi apenas peneirado para esta granulometria, não sendo necessária a moagem.

Um estudo foi realizado para verificar o tamanho de partícula máximo que poderia pirolisar no comprimento do forno existente e na temperatura selecionada. Partículas maiores poderiam não evaporar no comprimento do tubo e partículas menores poderiam aglomerar e entupir o tubo de injeção. Os detalhes do estudo estão apresentados no Anexo I.

Um microscópio ótico (Stereomasters, da Fischer Scientifics) foi usado para observar as partículas de PE e PS, conforme a Figura 10. Observa-se que as partículas de PS têm formato mais irregulares, em razão da necessidade de moagem do PS. As partículas de PE são mais homogêneas, como esferas. As propriedades físicas e o formato das partículas são fatores importantes para a fluidização das mesmas.

a)

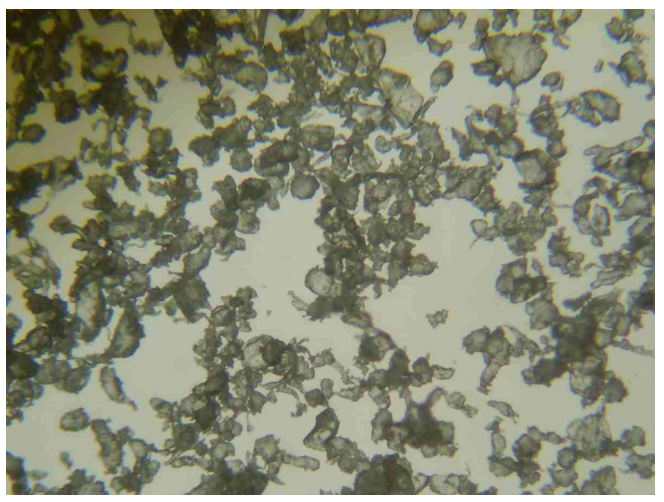

Figura 10 - Partículas de 38-125 $\mu \mathrm{m}$ de diâmetro (zoom 4X) a) PS e b) PE.

A resina XAD-4 foi usada para a absorção dos $\mathrm{PAH}$. O material foi seco em estufa a $50^{\circ} \mathrm{C}$ e em seguida peneirado para separar as partículas muito pequenas 
que podiam passar pelo papel de filtro $(<130 \mu \mathrm{m})$. As partículas maiores, então, foram tratadas em um extrator Sohlex com cloreto de metileno para que a resina estivesse isenta de compostos orgânicos antes da amostragem. Depois de pelo menos 10 horas de lavagem (extração), o XAD-4 foi levado a uma estufa a $50^{\circ} \mathrm{C}$ por pelo menos 24 horas para mantê-lo isento de umidade.

\subsection{Equipamentos}

Os ensaios de pirólise e combustão foram realizados no Combustion Laboratory, do Mechanical and Industrial Engineering Department, na Northeastern University em Boston, Estados Unidos.

Os testes de pirólise e de combustão foram conduzidos em um equipamento de dois estágios (Figura 11), de fluxo contínuo e eletricamente aquecido. Em cada estágio foi usado um tubo de quartzo (fabricado pela ATS) de $3 \mathrm{~cm}$ de diâmetro interno e com espessura de $0,25 \mathrm{~cm}$. O comprimento do tubo do forno superior é de $30,48 \mathrm{~cm}$ e o segundo forno de 60,96 cm. Observa-se na Figura 12 o detalhe do forno superior com o isolamento térmico e os elementos aquecedores.
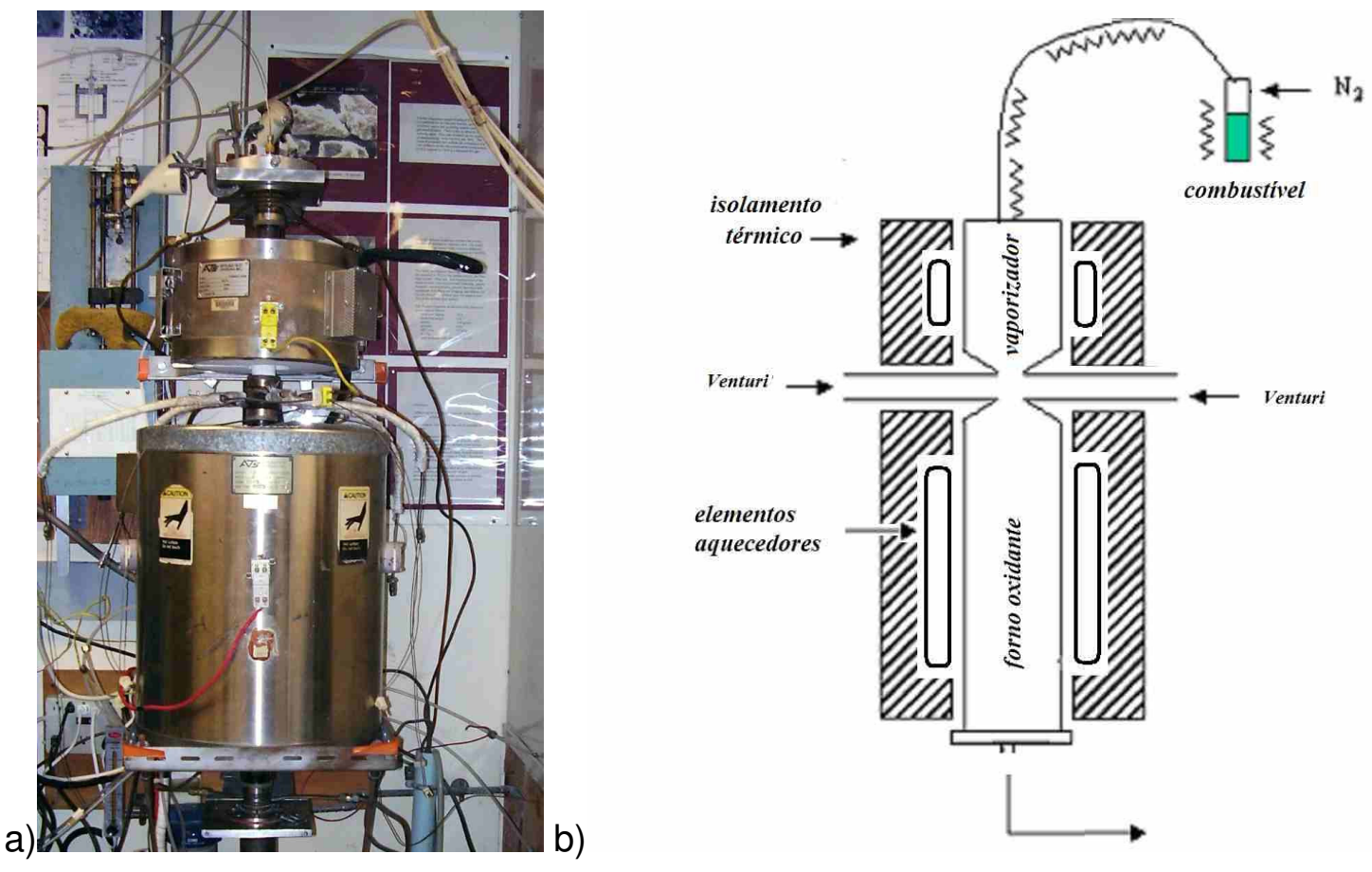

Figura 11 - a) Forno utilizado nos ensaios e b) Esquema ilustrativo. 


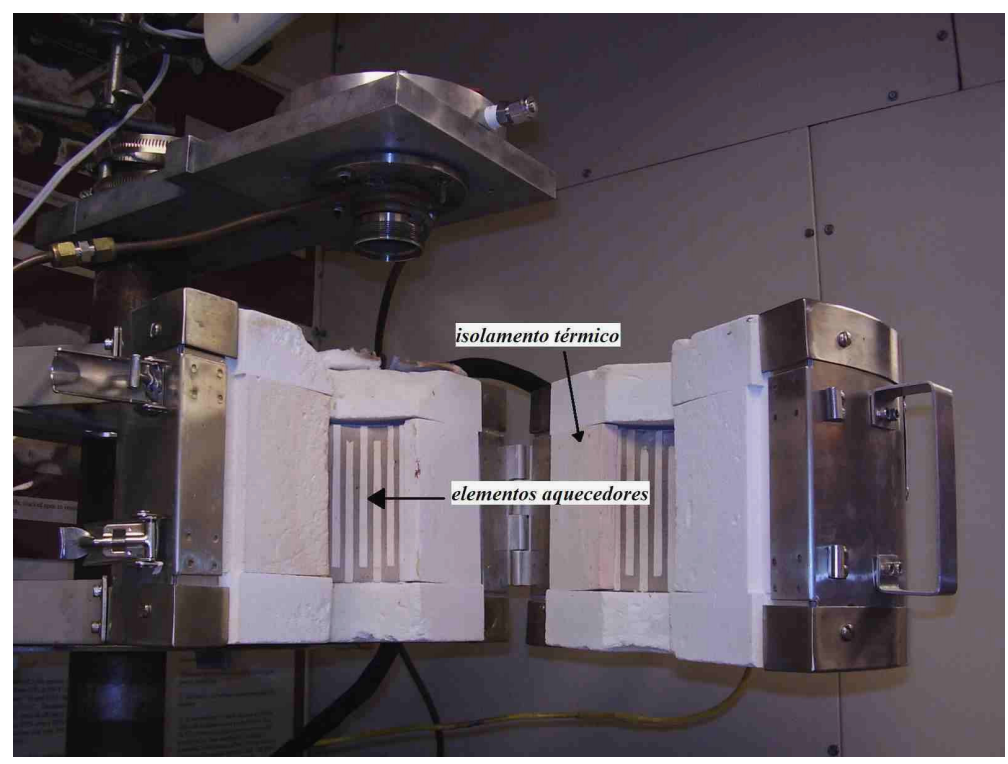

Figura 12 - Elementos aquecedores e o isolamento térmico.

Para introduzir o combustível no primeiro forno, uma agulha injetou em velocidade constante uma quantidade especifica do material. As partículas do combustível entraram com uma corrente de $\mathrm{N}_{2}$ por um injetor de aço inoxidável no forno pré-aquecido. O sistema de fluidização, usado para direcionar as partículas para dentro do forno, é composto por um longo tubo de 1,14 mm de diâmetro (da MicroGroup) e dois vibradores Vibro-Graver, da Alltech (detalhes na Figura 13). O tubo em que as partículas foram conduzidas e o tubo de ensaio foram vibrados para garantir o não impedimento das partículas no injetor no forno (entupimento).

O combustível foi então pirolisado no primeiro forno. O efluente passou através de um venturi de $8 \mathrm{~mm}$ de diâmetro, onde foi misturado com quatro jatos perpendiculares radialmente posicionados de um fluxo de gás pré-aquecido de nitrogênio e oxigênio (Figura 14). A mistura dos gases dos jatos com o efluente gasoso da combustão ou da pirólise ocorreu no venturi. Esta mistura foi então conduzida ao pós-queimador onde ocorreu a combustão dos gases presentes. 


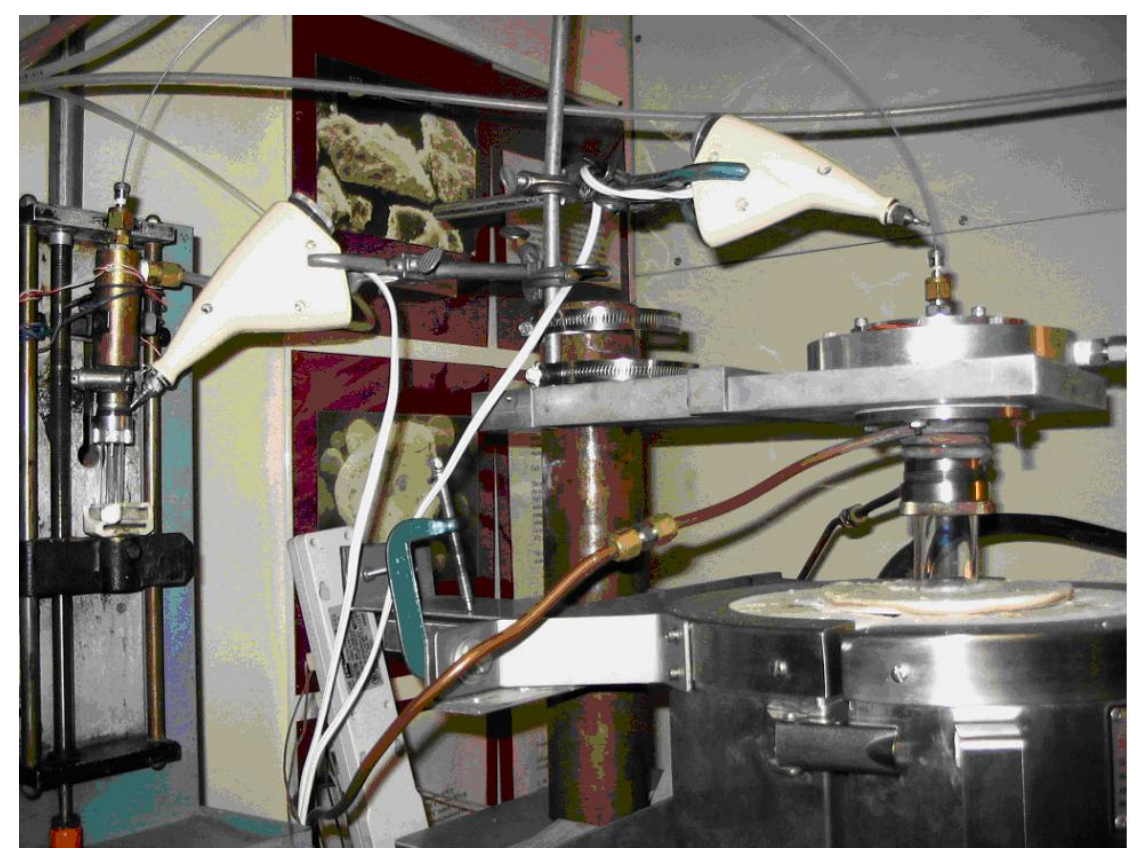

Figura 13 - Detalhe do sistema de injeção das partículas.

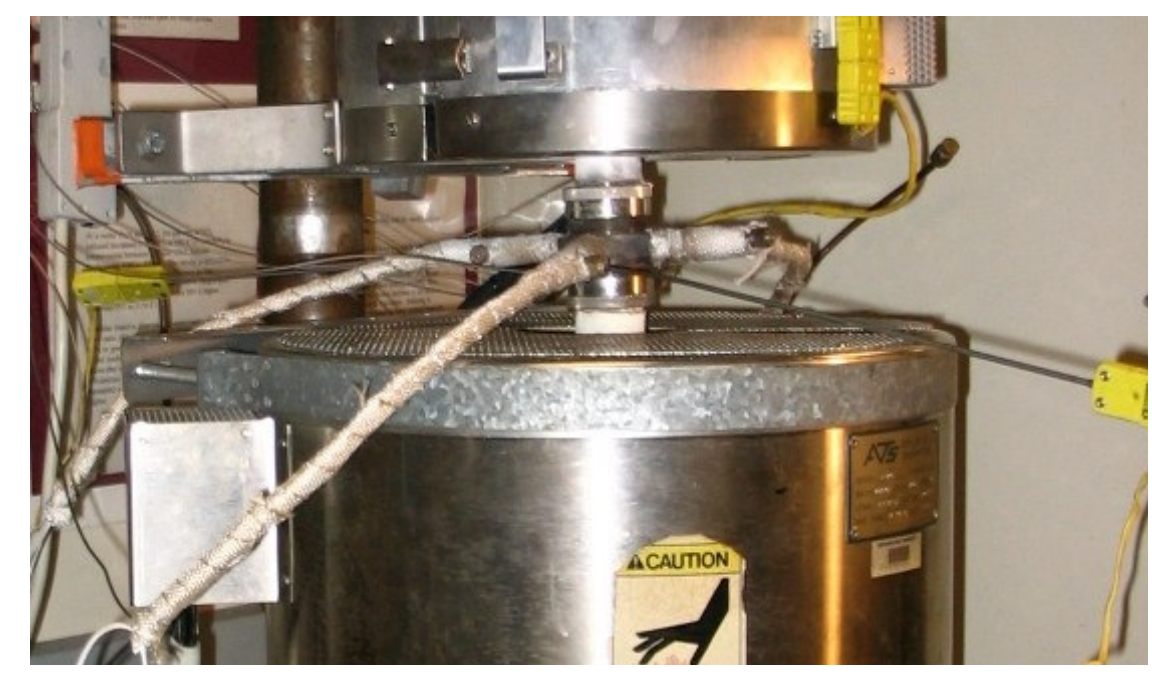

Figura 14 - Venturi entre os fornos para injeção de ar.

\subsubsection{Perfil de temperatura dos fornos}

O perfil de temperatura do gás foi obtido na linha central dos fornos de pirólise e de oxidação. Foi usado um termopar do tipo K, de 48 polegadas da Omega. Os resultados são apresentados na Figura 15, em que pode-se observar que após a saída do injetor, a partícula de polímero percorreu $5 \mathrm{~cm}$ no tubo de quartzo antes de 
entrar no forno de pirólise, e então percorreu $3,5 \mathrm{~cm}$ dentro do forno antes de alcançar a zona de aquecimento. O comprimento da zona de aquecimento do forno superior é de $11 \mathrm{~cm}$, e então a partícula teve que pirolisar/gaseificar antes de sair da zona de aquecimento, desse modo, percorrendo $19,5 \mathrm{~cm}$. Contudo, depois da zona de aquecimento, existem $3,5 \mathrm{~cm}$ antes do fim do forno, que serviram como um "comprimento extra" para pirolisar a partícula, mesmo que em uma temperatura mais baixa da temperatura central do forno.

Depois da pirólise, o gás alcança o venturi, onde a temperatura cai para aproximadamente $200^{\circ} \mathrm{C}$. Em seguida, quando o gás entra no segundo forno, ele alcança novamente a temperatura máxima dentro da zona de aquecimento, que é a nominal do forno de oxidação.

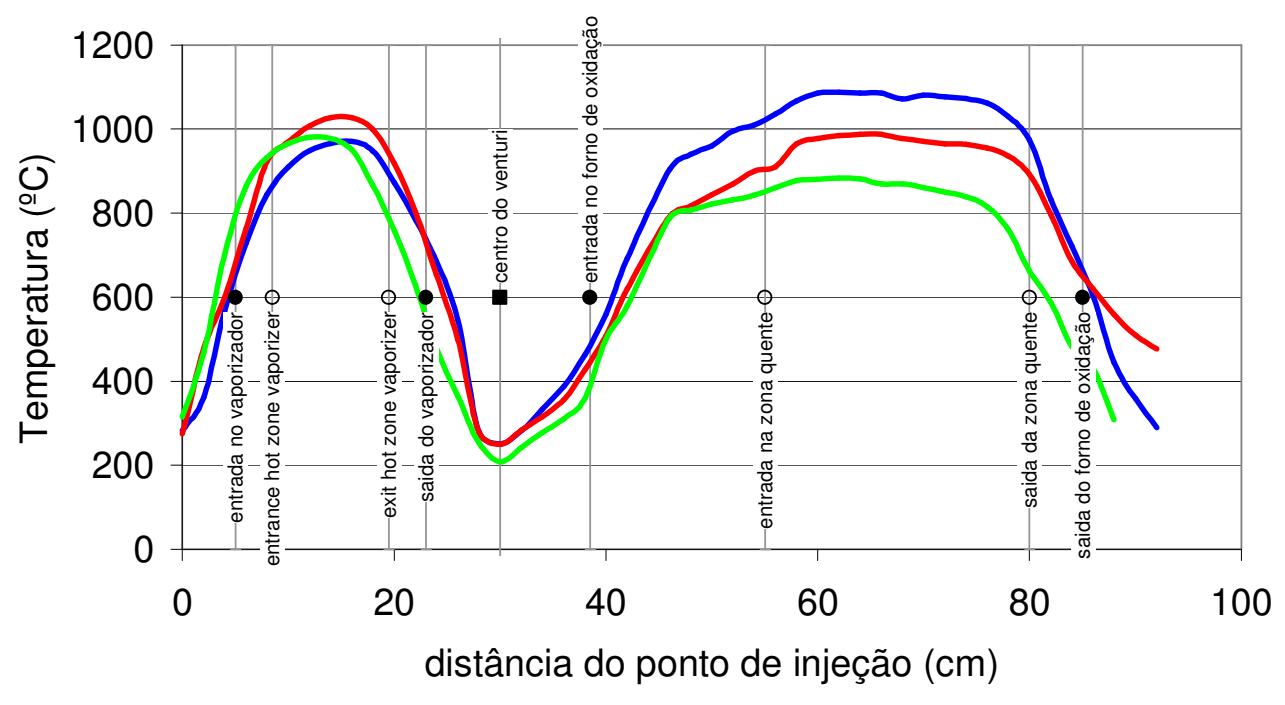

$-T$ forno $=1100 \mathrm{C} \quad-\mathrm{T}$ forno $=1000 \mathrm{C} \quad-\mathrm{T}$ forno $=900 \mathrm{C}$

Figura 15 - Perfil de temperatura nos fornos de vaporização e oxidação.

Tanto a distribuição de temperatura quanto a velocidade do gás nos fornos foram medidas seguindo a modelagem matemática, usando o programa de simulação Fluent 6.0, da mesma maneira que DeCoster et al. e Cumper et al. $[53,54]$. 


\subsubsection{Cálculo e simulação da gaseificação da partícula dos polímeros}

Os cálculos foram realizados para determinar se a vaporização das partículas de PE e PS injetadas no diâmetro de $+38-125 \mu \mathrm{m}$ iria acontecer no comprimento existente no primeiro forno, de até $19,5 \mathrm{~cm}$.

Três parâmetros foram computados no cálculo: o tempo para gaseificar uma partícula, o comprimento que a partícula percorre antes de gaseificar e a velocidade da partícula durante o trajeto. Para este cálculo (detalhado no Anexo I), foram usados incrementos de $10^{\circ} \mathrm{C}$ na temperatura da partícula, iniciando na temperatura ambiente e finalizando na temperatura de pirólise do polímero estudado, assumida como sendo $500^{\circ} \mathrm{C}$ para o PE, e $405^{\circ} \mathrm{C}$ para o PS [3]. Depois da partícula alcançar essa temperatura, foi assumido que a massa da partícula aumentou em temperatura constante. Assim, passos iterativos foram usados subtraindo $5 \mu \mathrm{m}$ do diâmetro da partícula até a completa gaseificação. Em cada iteração, a temperatura da parede do forno foi aproximada usando o perfil de temperatura mostrado na Figura 15. Os resultados destes cálculos foram comparados com os resultados da simulação computacional executada com o programa Fluent 6.0, usando o código numérico de diferenças finitas.

No método de simulação computacional, o forno foi projetado no software Gambit como um cilindro 3D. O código foi usado para prever a gaseificação de uma única "gota", liberada com velocidade inicial do injetor, correspondente à vazão de $\mathrm{N}_{2}$ entrando no forno. Os dados de entrada deste sistema foram a temperatura do forno, a temperatura inicial da partícula e do gás, e ainda as propriedades do fluido produzido na pirólise e dos materiais (do gás, polímero e da parede do forno). $O$ programa calculou a transferência convectiva de calor e massa da partícula, e sua trajetória por um balanço de massa.

$O$ tempo de residência do $\mathrm{N}_{2}$ fluindo no forno gaseificador foi encontrado como sendo 1,60 e 1,56 segundos nos métodos de simulação e cálculo, respectivamente. Na Figura 16 são mostrados os resultados calculados pelos dois métodos acima descritos do aquecimento da partícula, o tempo de gaseificação ao longo da linha central do forno, e a distância percorrida por uma partícula de $125 \mu \mathrm{m}$.

No método de cálculo, o tempo de gaseificação da partícula de PE foi encontrado como sendo de 160 ms e de 241 ms para o PS; no método de simulação o resultado foi muito similar, 154 ms para o PE e 152 ms para o PS. 
A distância que a partícula sólida de PE percorreu no processo de pirólise foi de $6,15 \mathrm{~cm}$ no cálculo e $9,76 \mathrm{~cm}$ na simulação. A distância percorrida pelo PS foi de 9,60 e 9,33 cm, respectivamente no cálculo e simulação. Estes valores ainda são muito menores do que o disponível de $19,5 \mathrm{~cm}$ do forno pirolisador. Mesmo que seja considerado um erro de 100\% na distância encontrada, ainda assim, a partícula de $125 \mu \mathrm{m}$ irá gaseificar na zona quente do forno de pirólise. O tempo de gaseificação da partícula encontrada aqui é menor que os encontrados experimentalmente por

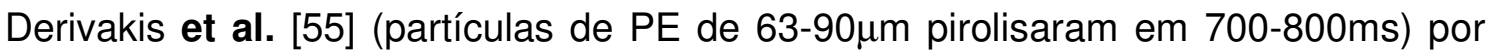
causa das maiores taxas de aquecimento do presente trabalho.

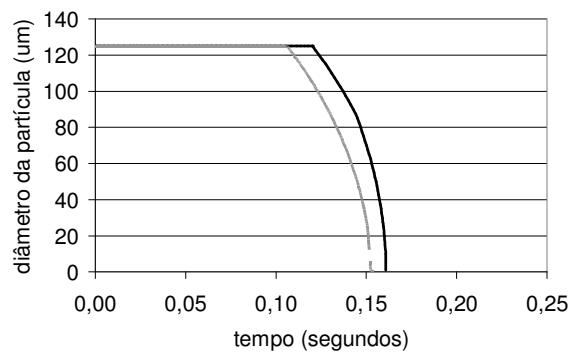

a)

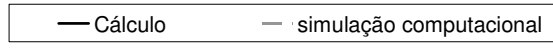

b)

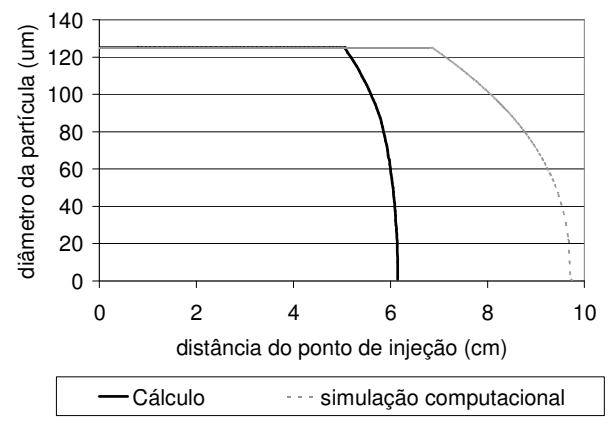

Figura 16 - Diâmetro de uma partícula de PE versus a) tempo para gaseificar e b) distância percorrida.

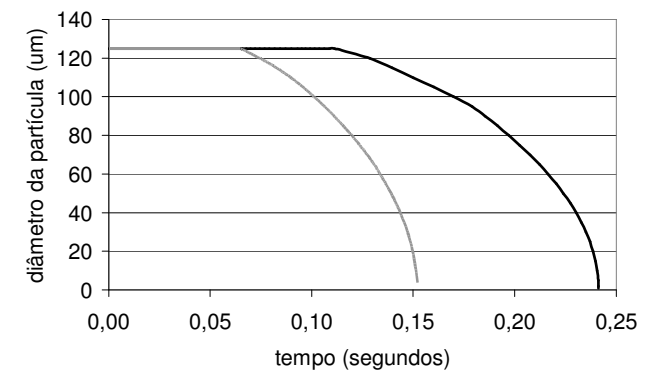

a)

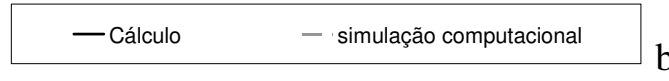

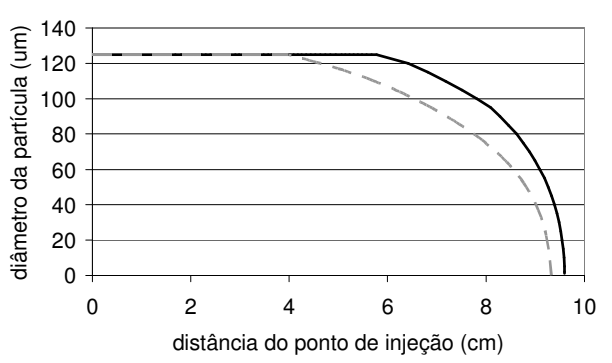

b)

- simulação computacional

Figura 17 - Diâmetro de uma partícula de PS versus a) tempo para gaseificar e b) distância percorrida.

Os ensaios experimentais mostraram que é difícil evitar algum entupimento das partículas de polímero em razão das forças eletrostáticas, especialmente quando razões equivalentes altas são implantadas, o que altera efetivamente o tamanho da partícula. Contudo, essa análise teórica sugere que é possível gaseificar 
as partículas de PE e PS neste forno específico, mesmo que adversidades possam ocorrer.

\subsubsection{Ensaios de pirólise}

Os testes de pirólise serviram para avaliar se a concentração dos compostos químicos estudados aumentaram ou diminuíram antes e depois da combustão, na tentativa de estabelecer a formação ou consumo destes nas reações de oxidação presentes.

Particularmente nestes testes, um dos fornos (o primeiro) não foi utilizado e as partículas entraram diretamente no segundo forno (de $60,96 \mathrm{~cm}$ ), que foi usado para pirolisar o polímero com nitrogênio a $1000^{\circ} \mathrm{C}$, como mostrado na Figura 18. Esta temperatura foi escolhida pois, caso fosse menor, talvez não houvesse tempo de vaporizar o material em menos de 1 segundo, disponível desde a injeção até a saída da zona de aquecimento do forno.

Como citado anteriormente, na pirólise do PE ocorre a conversão de maior parte de sua massa para produtos gasosos. Do contrário, o PS pirolisa principalmente como líquidos, graxas e óleos, com apenas uma fração gasosa. Porém, naqueles estudos de pirólise do PS foram usadas temperaturas de até $700^{\circ} \mathrm{C}$. No sistema usando forno vertical era esperado que todo o polímero gaseificasse. Para isso foi usado um forno com fluxo não muito alto de gases (2 lpm) e com temperatura $\left(T=1000^{\circ} \mathrm{C}\right)$ suficiente para que o polímero além de pirolisar, tivesse tempo de gaseificar-se completamente. 


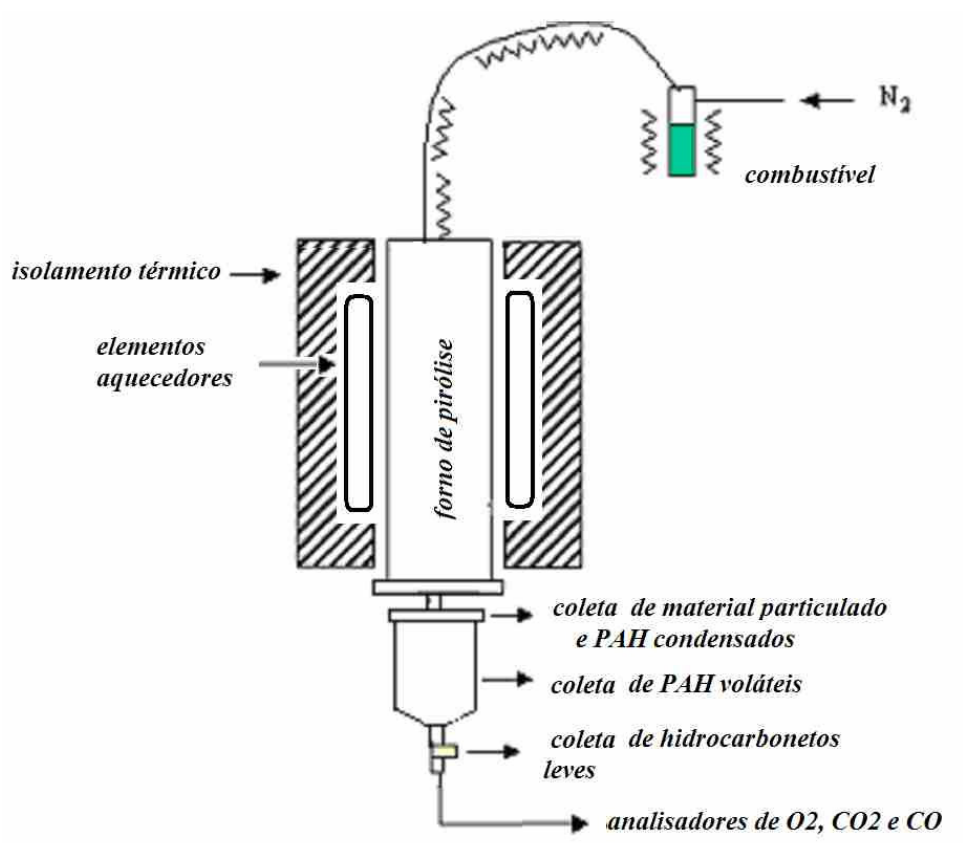

Figura 18 - Forno usado nos ensaios de pirólise com os pontos de coletas de produtos.

Foram coletados os hidrocarbonetos leves (HL) e os PAH (condensados e voláteis) no final do forno com o sistema da Graseby mostrado na Figura 19. Este sistema é formado por um papel de filtro da Whatman, para coleta do material particulado e PAH condensado, seguido de um recipiente no qual se localiza a resina $\mathrm{XAD}$, para coleta dos $\mathrm{PAH}$ voláteis.

O gás efluente seguiu para um condensador (banho de gelo) em que a umidade ficou retida. Em seguida, nos analisadores online, foram monitoradas as emissões de $\mathrm{CO}$ e $\mathrm{CO}_{2}$, garantindo que não estivessem ocorrendo reações de oxidação indesejadas dentro do forno e, portanto, nenhum $\mathrm{O}_{2}$ estivesse entrando no sistema. As condições médias dos testes realizados estão apresentadas na Tabela 2.

Apesar do termo "razão equivalente" não ser adequado para a pirólise, visto não haver oxigênio presente, neste trabalho encontrou-se a relação da taxa de alimentação das partículas no forno de pirólise com a razão equivalente obtida na combustão e usou-se este valor para comparar as emissões de pirólise e combustão, podendo posicionar corretamente os dados nos gráficos. 
Tabela 2 - Dados dos testes de pirólise realizados.

\begin{tabular}{lcc}
\hline \multicolumn{1}{c}{ Material } & $\mathrm{PS}$ & $\mathrm{PE}$ \\
\hline Razão equivalente teórica / material & 1,5 & 1,5 \\
\hline Vazão de $\mathrm{N}_{2}$ no forno de pirólise $(\mathrm{lpm})$ & $2,08 \pm 0,10$ & $2,20 \pm 0,00$ \\
\hline Vazão de partículas $(\mathrm{g} / \mathrm{min})$ & $0,60 \pm 0.02$ & $0,64 \pm 0,06$ \\
\hline Temperatura do forno de pirólise $\left({ }^{\circ} \mathrm{C}\right)$ & $1000 \pm 00$ & $1000 \pm 00$ \\
\hline Número de testes & 4 & 2 \\
\hline Tempo duraçao dos testes $(\mathrm{min})$ & $2,98 \pm 0,40$ & $3,33 \pm 0,38$ \\
\hline
\end{tabular}

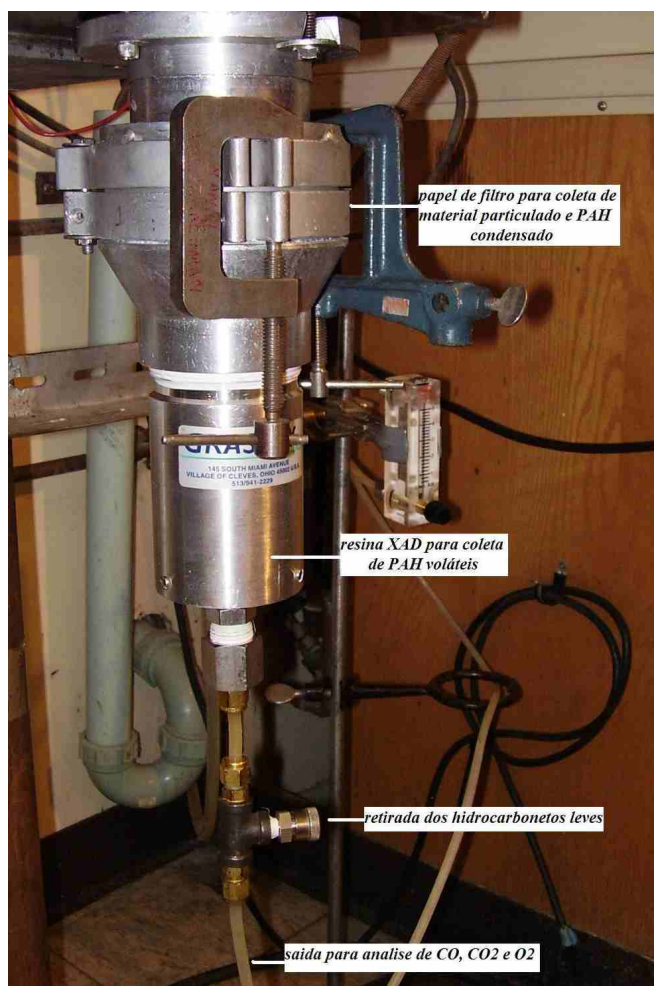

Figura 19 - Sistema de coleta de material particulado total, PAH e HL.

\subsubsection{Ensaios de pirólise seguida de combustão}

A taxa de injeção das partículas no forno de pirólise foi controlada de acordo com a razão equivalente desejada no forno de combustão para cada teste. A concentração de $\mathrm{O}_{2}$ escolhida para o forno de combustão foi de $21 \%$. Este valor foi escolhido para que se pudesse comparar com outros estudos realizados na mesma concentração. Se a mistura gasosa obtida da pirólise dos plásticos fosse misturada diretamente com ar $\left(21 \% \mathrm{O}_{2}\right)$, a concentração dentro do forno de combustão seria de apenas $11 \%$. 
Nestes ensaios o forno foi usado como mostrado na Figura 20, isto é, o forno de pirólise, com coleta de HL no venturi, forno de combustão com coleta de HL, $\mathrm{PAH}$, material particulado total e medições online de $\mathrm{CO}, \mathrm{CO}_{2}$ e $\mathrm{O}_{2}$ na saída do forno de oxidação. As condições médias dos ensaios estão mostradas na Tabela $3 \mathrm{e}$ Tabela 4. O número total de ensaios em cada temperatura está mostrado na Tabela 5.

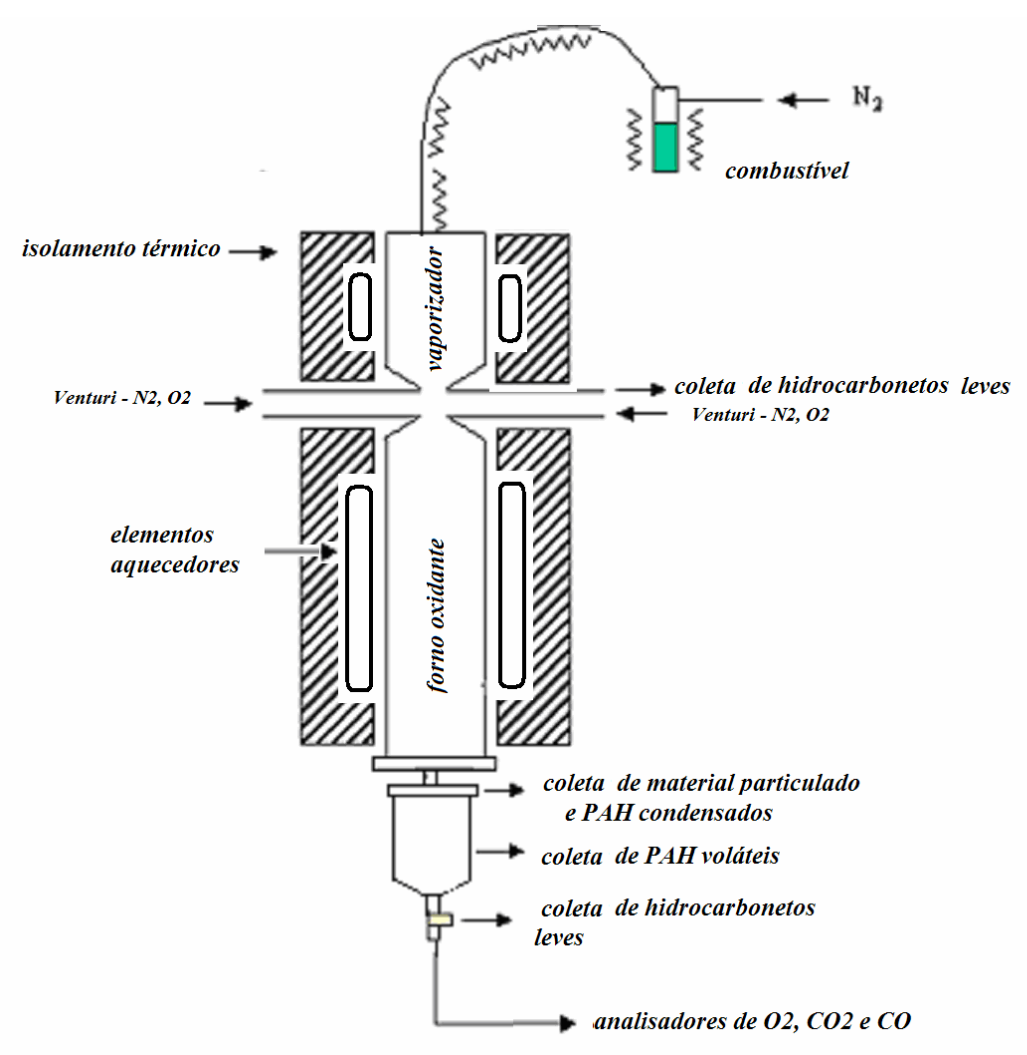

Figura 20 - Forno usado nos ensaios de pirólise seguida de combustão, com os pontos de coletas de produtos.

A temperatura do forno de pirólise foi mantida em $1000^{\circ} \mathrm{C}$ e do forno de combustão foi variada em 900,1000 e $1100^{\circ} \mathrm{C}$. É importante ressaltar que a diferença da vazão dos gases teórica e a utilizada, deve-se à pressão existente no cilindro de gases e à perda de carga no tubo de conexão do cilindro ao forno. Porém, para garantir que $21 \%$ de $\mathrm{O}_{2}$ estivesse presente no forno de combustão, antes de cada teste, as vazões dos gases foram ajustadas para garantir $21 \%$ de $\mathrm{O}_{2}$. 
Tabela 3 - Dados dos testes de pirólise seguida de combustão com PS.

\begin{tabular}{lcccc}
\hline \multicolumn{1}{c}{$\begin{array}{c}\text { Razão equivalente teórica no forno de } \\
\text { combustão }\end{array}$} & 0,5 & 1,0 & 1,5 & 2.0 \\
\hline Vazão de $\mathrm{N}_{2}$ no forno de pirólise (Ipm) & $2,00 \pm 0,00$ & $2,02 \pm 0,04$ & $2,00 \pm 0,00$ & $2,00 \pm 0,00$ \\
\hline Vazão de $\mathrm{N}_{2}$ no forno de combustão $(\mathrm{lpm})$ & $1,23 \pm 0,16$ & $1,13 \pm 0,11$ & $1,20 \pm 0,00$ & $1,11 \pm 0,08$ \\
\hline Vazão de $\mathrm{O}_{2}$ no forno de combustão (lpm) & $0,96 \pm 0,02$ & $0,96 \pm 0,04$ & $1,00 \pm 0,00$ & $0,96 \pm 0,02$ \\
\hline Vazão de partículas (g/min) & $0,20 \pm 0,02$ & $0,57 \pm 0,93$ & $0,72 \pm 0,12$ & $1,16 \pm 0,20$ \\
\hline Temperatura do forno de pirólise ( $\left.{ }^{\circ} \mathrm{C}\right)$ & $1031 \pm 63$ & $992 \pm 50$ & $1020 \pm 2$ & $985 \pm 12$ \\
\hline Tempo de duração dos testes (min) & $5,00 \pm 1,33$ & $4,09 \pm 0,28$ & $3,00 \pm 0,00$ & $2,04 \pm 0,10$ \\
\hline
\end{tabular}

Tabela 4 - Dados dos testes de pirólise seguida de combustão com partículas de PE.

\begin{tabular}{lcccc}
\hline $\begin{array}{c}\text { Razão equivalente teórica no forno de } \\
\text { combustão }\end{array}$ & 0,5 & 1,0 & 1,5 & 2.0 \\
\hline Vazão de $\mathrm{N}_{2}$ no forno de pirólise (lpm) & $2,00 \pm 0,00$ & $1,97 \pm 0,17$ & $2,03 \pm 0,08$ & $2,00 \pm 0,02$ \\
\hline Vazão de $\mathrm{N}_{2}$ no forno de combustão $(\mathrm{lpm})$ & $1,25 \pm 0,10$ & $1,09 \pm 0,17$ & $1,25 \pm 0,14$ & $1,16 \pm 0,13$ \\
\hline Vazão de $\mathrm{O}_{2}$ no forno de combustão $(\mathrm{lpm})$ & $0,98 \pm 0,02$ & $0,94 \pm 0,05$ & $0,97 \pm 0,03$ & $0,95 \pm 0,01$ \\
\hline Vazão de partículas (g/min) & $0,18 \pm 0,02$ & $0,35 \pm 0,04$ & $0,52 \pm 0,05$ & $0,74 \pm 0,06$ \\
\hline Temperatura do forno de pirólise $\left({ }^{\circ} \mathrm{C}\right)$ & $1060 \pm 25$ & $1007 \pm 30$ & $1029 \pm 33$ & $1014 \pm 37$ \\
\hline Tempo de duração dos testes (min) & $5,75 \pm 0,50$ & $4,86 \pm 0,90$ & $4,17 \pm 0,41$ & $3,68 \pm 0,72$ \\
\hline
\end{tabular}

Tabela 5 - Testes realizados, temperaturas e número de testes.

\begin{tabular}{lcc}
\hline Pirólise seguida de combustão & Temperatura do forno de oxidação & $\mathrm{N}^{\circ}$ de testes \\
\cline { 2 - 3 } & $900^{\circ} \mathrm{C}$ & 7 \\
\cline { 2 - 3 } & $1000^{\circ} \mathrm{C}$ & 11 \\
\cline { 2 - 3 } & $1100^{\circ} \mathrm{C}$ & 9 \\
\hline PS (Forno de pirólise $-1000^{\circ} \mathrm{C}$ (Forno de pirólise $\left.-1000^{\circ} \mathrm{C}\right)$ & $900^{\circ} \mathrm{C}$ & 6 \\
\cline { 2 - 3 } & $1000^{\circ} \mathrm{C}$ & 8 \\
\cline { 2 - 3 } & $1100^{\circ} \mathrm{C}$ & 7 \\
\hline
\end{tabular}

Hidrocarbonetos leves foram coletados no venturi (conforme pode ser observado na Figura 21), e os produtos de combustão (hidrocarbonetos leves, PAH, e total de material particulado) foram coletados no final do forno de combustão (Figura 19). O gás efluente seguiu para os analisadores online, para monitorar as emissões de $\mathrm{CO}$ e $\mathrm{CO}_{2}$ e medir o consumo de $\mathrm{O}_{2}$. 


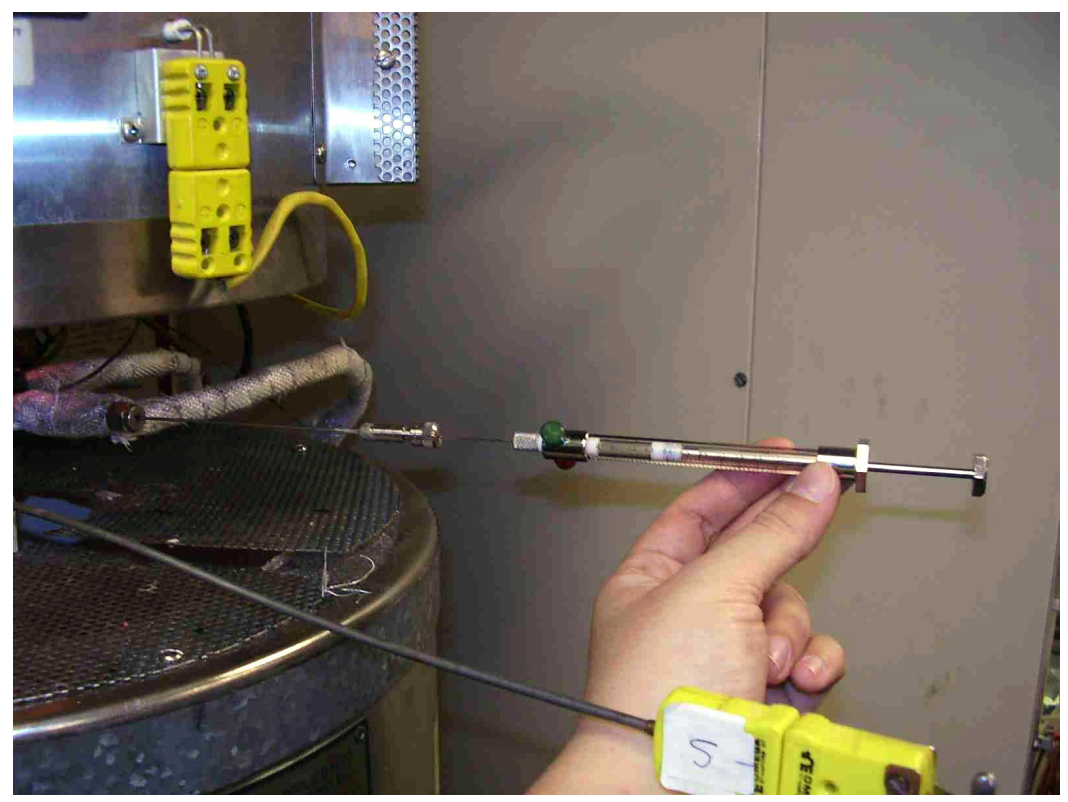

Figura 21 - Detalhe do sistema de coleta de HL no venturi.

\subsubsection{Caracterização do material particulado}

As emissões de material particulado foram medidas no mesmo forno, porém um separador de material particulado substituiu o coletor de PAH da Figura 19.

Para caracterizar a emissão de materiais particulados, o sistema de coleta de amostra foi utilizado ao final do forno, como mostrado na Figura 22. Foi usado um coletor de partículas de múltiplos estágios da Andersen, que simula o sistema respiratório humano. Ele é composto de uma série de placas perfuradas, sendo cada uma destas placas um estágio (veja na Figura 23). Em cada estágio o tamanho dos furos e a sua distribuição resultam em faixas de granulometria das partículas em: +95,$8 ;+5,8-4,7 ;+4,7-3,3 ;+3,3-2,1 ;+2,1-1,1 ;+1,1-0,7$ e +0,7-0,4 $\mu$ m. Entre cada estágio ficam apoiados discos metálicos em que se depositam as partículas daquele estágio, e as partículas mais leves passam pelo disco para o próximo estágio. O aparato tem no final um filtro que retém qualquer partícula restante $<0,4 \mu \mathrm{m}$.

Os pratos foram pesados antes e depois, para calcular a quantidade produzida nos diferentes tamanhos de partículas. De modo a garantir que não contivesse água no material particulado pesado, após o ensaio e antes da pesagem, o aparato separador das partículas foi colocado na estufa por aproximadamente 2 
horas a $50^{\circ} \mathrm{C}$. Também foram coletados os hidrocarbonetos leves da pirólise (produtos de pirólise) e os gases $\mathrm{CO}, \mathrm{CO}_{2}$ e $\mathrm{O}_{2}$ no final da combustão.

O aparato de coleta do material particulado foi conectado a uma bomba, que exige uma vazão total de gases de $25 \mathrm{lpm}$ para seu perfeito funcionamento. Portanto, no final do forno de combustão, um tubo com entrada de ar foi conectado, chamado aqui de ar de diluição. Assim, os resultados obtidos de $\mathrm{CO}$ e $\mathrm{CO}_{2}$ tiveram que ser convertidos para seu valor concentrado, isto é, desconsiderando a diluição.

Para os testes com PS, o forno de pirólise foi mantido a $1000^{\circ} \mathrm{C}$ e o forno de combustão em $1100^{\circ} \mathrm{C}$. Nos testes de PE, a temperatura do forno de combustão variou em 1000 e $1100^{\circ} \mathrm{C}$. Os dados dos testes estão apresentados na Tabela 6.

Tabela 6 - Dados dos testes realizados.

\begin{tabular}{lccc}
\hline \multicolumn{1}{c}{ Material } & PS & PE & PE \\
\hline Razão equivalente teórica / material & $1,26 \pm 0,14$ & $1,55 \pm 0,16$ & $1,31 \pm 0,06$ \\
\hline Vazão de $\mathrm{N}_{2}$ no forno de pirólise $(\mathrm{lpm})$ & $2,00 \pm 0,00$ & $2,00 \pm 0,03$ & $1,98 \pm 0,03$ \\
\hline Vazão de $\mathrm{N}_{2}$ no forno de combustão $(\mathrm{lpm})$ & $1,30 \pm 0,00$ & $1,20 \pm 0,03$ & $1,00 \pm 0,03$ \\
\hline Vazão de $\mathrm{O}_{2}$ no forno de combustão $(\mathrm{lpm})$ & $0,98 \pm 0,03$ & $1,00 \pm 0,00$ & $1,00 \pm 0,00$ \\
\hline Vazão de partículas $(\mathrm{g} / \mathrm{min})$ & $0,75 \pm 0,14$ & $0,72 \pm 0,02$ & $0,71 \pm 0,00$ \\
\hline Vazão de ar de diluição $(\mathrm{lpm})$ & $21,25 \pm 0,29$ & $21,50 \pm 0,71$ & $21,00 \pm 0,50$ \\
\hline Temperatura do forno de pirólise $\left({ }^{\circ} \mathrm{C}\right)$ & $1061 \pm 15$ & $1002 \pm 60$ & $1002 \pm 60$ \\
\hline Temperatura do forno de oxidação $\left({ }^{\circ} \mathrm{C}\right)$ & 1100 & 1000 & 1100 \\
\hline Número de testes & 4 & 2 & 2 \\
\hline Tempo de duração dos testes $(\mathrm{min})$ & $8,92 \pm 3,59$ & & $12,01 \pm 0,26$ \\
\hline
\end{tabular}

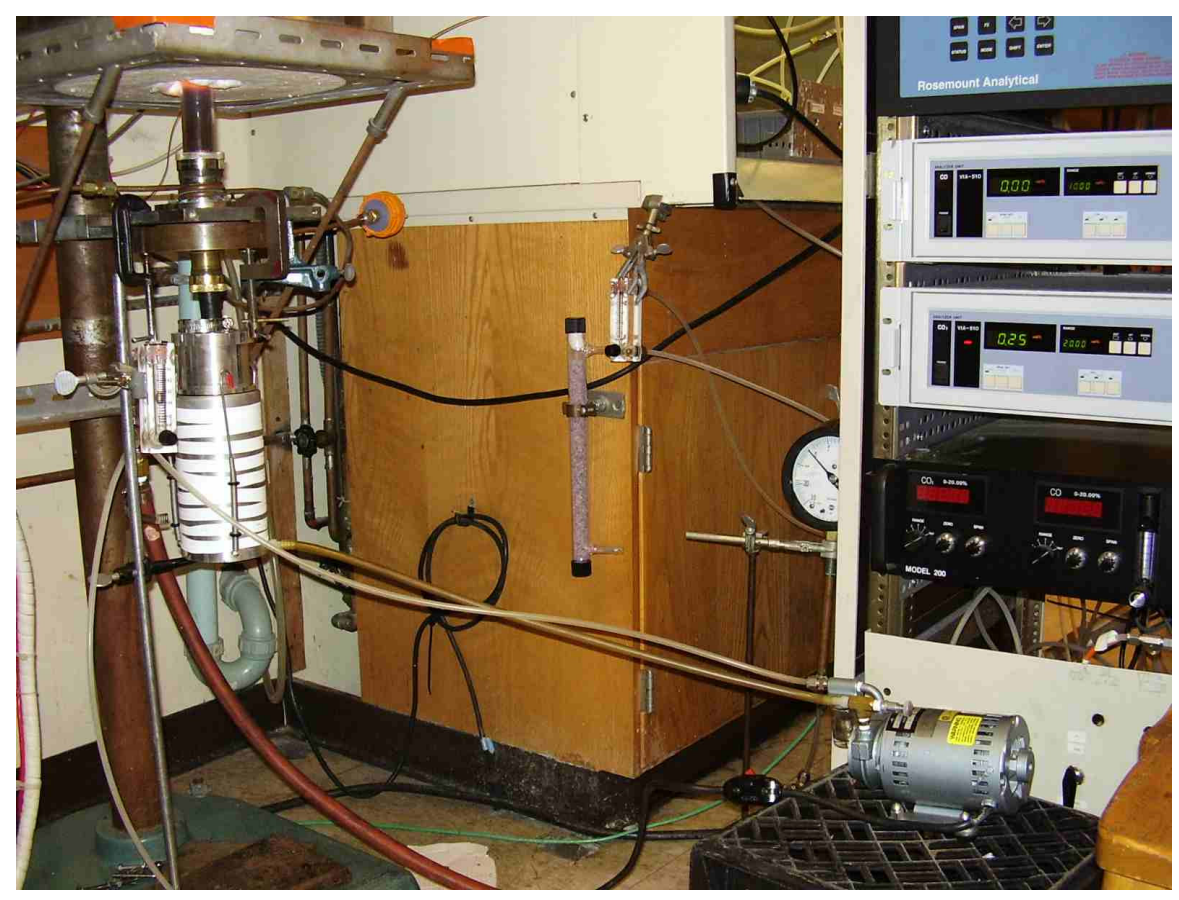

Figura 22 - Aparato de coleta de material particulado para caracterização. 


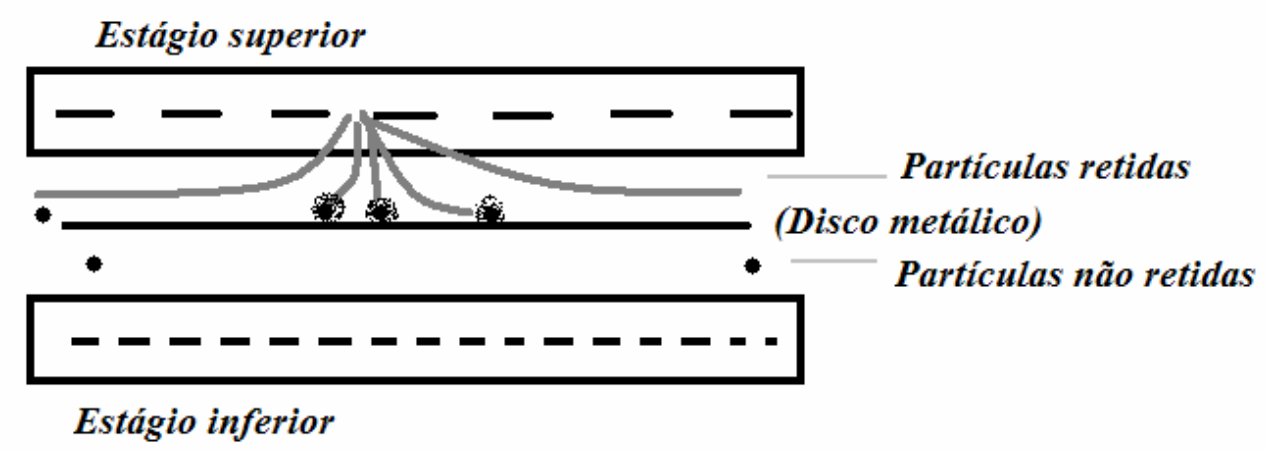

Figura 23 - Esquema do separador de partículas.

\subsection{Análise dos compostos emitidos}

\subsubsection{Hidrocarbonetos leves por cromatografia gasosa}

Os efluentes gasosos dos fornos de pirólise e de combustão foram amostrados com uma seringa de $100 \mu \mathrm{L}$ e injetados num equipamento da Agilent de cromatografia gasosa Série 6890 (Figura 24). Os HL foram analisados com uma coluna capilar $\mathrm{HP}-5 / \mathrm{Al}_{2} \mathrm{O}_{3} 30 \mathrm{~m} \times 0,32 \mathrm{~mm}$ com um filme de $0,25 \mu \mathrm{m}$ de espessura, conectado a um detector de ionização de chama.

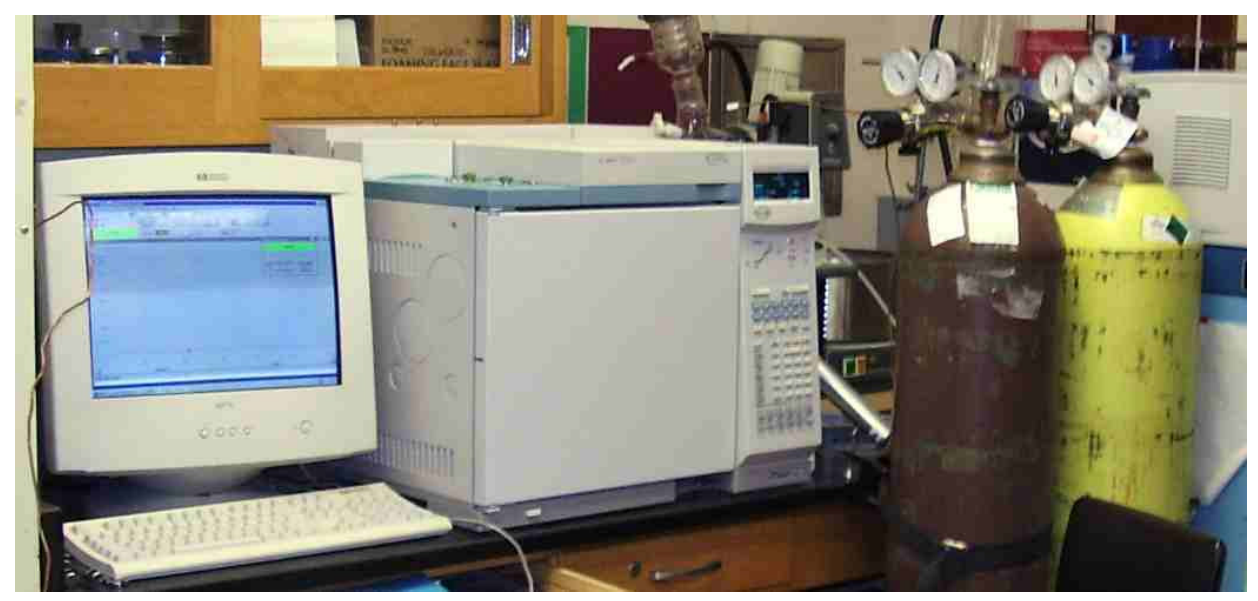

Figura 24 - Aparelho de cromatografia (análises de $\mathrm{HL} \mathrm{e} \mathrm{N}_{2}, \mathrm{CO}, \mathrm{CO}_{2}$ e $\mathrm{O}_{2}$ ). 
Os resultados do teste foram comparados com injeções padrões, e assim as frações molares de cada composto puderam ser calculados. Os hidrocarbonetos leves identificados foram: metano, acetileno, etileno, etano, propileno, propino, propano, etilacetileno, 1,3-butadieno, trans-2-buteno, 1-buteno, isobutileno, cis 2buteno, $\mathrm{n}$ butano, benzeno, tolueno, etilbenzeno, mp-xileno e o-xileno.

\subsubsection{Gases $\mathrm{CO}, \mathrm{CO}_{2}$ e $\mathrm{O}_{2}$ por cromatografia gasosa}

O efluente gasoso do forno de combustão também foi amostrado com uma seringa de $100 \mu \mathrm{L}$ e injetado num equipamento da Agilent de cromatografia gasosa Série 6890 equipado com um detector de condutividade térmica para análise dos gases $\mathrm{CO}, \mathrm{CO}_{2}, \mathrm{O}_{2}$. Os resultados foram comparados com injeções padrão, e assim as frações molares de cada composto foram calculados.

Os resultados de $\mathrm{CO}, \mathrm{CO}_{2}$ e $\mathrm{O}_{2}$ obtidos por cromatografia gasosa foram usados apenas para confirmar os resultados dos analisadores online, e não serão apresentados. Os dados mostraram-se coerentes, porém a oscilação dos resultados é muito maior, já que a coleta destes gases é "pontual", isto é, acontece em apenas um período do teste, enquanto os resultados dos analisadores online são a média de todo o teste.

\subsubsection{Gases $\mathrm{CO}, \mathrm{CO}_{2}$ e $\mathrm{O}_{2}$ por analisadores online}

Os gases que saem do sistema do forno depois da coleta de PAH foram encaminhados para um condensador onde a umidade foi retirada, e então seguiram para análise online dos gases emitidos $\mathrm{CO}_{2}$ e $\mathrm{CO}$, e do $\mathrm{O}_{2}$ que não reagiu na combustão. Os gases $\mathrm{CO}$ e $\mathrm{CO}_{2}$ foram monitorados por um analisador infravermelho Horiba e $\mathrm{O}_{2}$ foi monitorado por um analisador paramagnético Beckman modelo 350 (ver Figura 25). Os dados obtidos foram armazenados em uma placa de aquisição de dados "Data Translation" modelo DT-322 em um computador, e depois foram calculadas as frações molares de cada composto emitido. 
a)
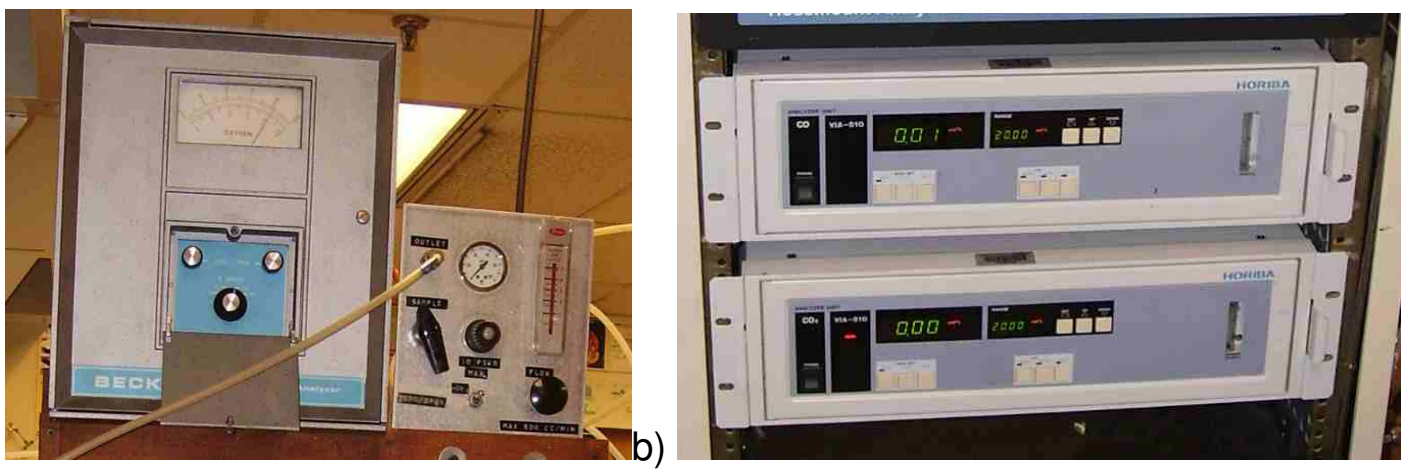

Figura 25 - Analisadores online a) $\mathrm{O}_{2}$; b) $\mathrm{CO}$ e $\mathrm{CO}_{2}$.

\subsubsection{Coleta, extração e análise de PAH}

Depois do ensaio terminado, o filtro e a resina XAD-4 foram removidos do sistema coletor e colocados juntos em frasco de vidro e armazenado em freezer na temperatura de $4^{\circ} \mathrm{C}$ até a análise em um equipamento de cromatografia gasosa. Antes da extração, $200 \mu \mathrm{L}$ de uma mistura de padrão interno foi diretamente adicionada ao filtro e a resina. A mistura de padrão interno foi preparada com quantidades iguais de cada um dos componentes: naftaleno-d8, acenaftaleno-d10, antraceno-d10, criseno-d12 e pireleno-d12.

As análises químicas foram gentilmente realizadas pelo Dr. Carlson, no US Army Natick Lab, Estados Unidos. O equipamento de cromatografia gasosa usado foi um Hewlett-Packard (HP) modelo 5890 equipado com um detector de seleção de massa. Os PAH foram extraídos da resina de XAD-4 de acordo com o método EPA 8270A, como especificado na metodologia analítica SW846. "Brancos" da resina e filtro também foram extraídos e analisados. Os isômeros foram quantificados de acordo com seu tempo de retenção. A identificação dos isômeros foi acompanhada pelo uso de padrões para cromatografia gasosa.

Os compostos avaliados foram (em ordem de peso molecular): estireno, benzaldeído, fenol, indeno, naftaleno, benzotiofeno, 2-metilnaftaleno, 1metilnaftaleno, bifenileno, bifenil, acenafteno, acenaftileno, dibenzofurano, fluoreno, 2-metilfluoreno, 1-metilfluoreno, estireno dimero, dibenzotiofeno, fenantreno, antraceno, 3-metilfenantreno, 2-metilfenantreno, 2-metilantraceno, $4 \mathrm{~h}$ ciclopenta(def)fenanf, 4-metilfenantreno, 1-metilfenantreno, fluoranteno, acefenantrileno, pireno, benzo[a]fluoreno, 11h-benzo[b]fluoreno, 1-metilpireno, 
benzo[ghi]fluoranteno, benzo[c]fenantreno, estireno trimero, ciclopenta[cd]pireno, benz[a]antraceno, trifenileno, criseno, benzo[b]fluoranteno, benzo[k]fluoranteno, benzo[a]fluoranteno, benzo[e]pireno, benzo[a]pireno, perileno, dibenz[a,j]antraceno, indeno[7,1,2,3-cdef]pireno, indeno[1,2,3-cd]pireno, benzo[ghi]perileno, antratreno, dibenz[a,h]antraceno, benzo[b]criseno e piceno.

\subsection{Tratamento dos dados}

\subsubsection{Cálculo das concentrações}

As emissões de $\mathrm{O}_{2}, \mathrm{CO}$ e $\mathrm{CO}_{2}$ são obtidos pelos analisadores online como volts e transformados em porcentagem de pressão parcial (pp\%). A conversão desse resultado para $\mathrm{mg} / \mathrm{g}$ de polímero inserido foi obtido por:

$$
\frac{m g}{g P o l_{\text {inserido }}}=\frac{p p \%}{100} \cdot \frac{\text { vazaototal }_{\text {gas }}}{0,082 \cdot T(300 K)} \cdot \frac{M M_{\text {gas }} \cdot 1000 \cdot t_{\text {teste }}}{g \text { Pol }_{\text {inserido }}} \quad \text { Equação } 10
$$

sendo a vazão total de gás em litros por minuto, $\mathrm{MM}_{\text {gas }}$ a massa molecular do gás analisado, $t_{\text {teste }} \mathrm{o}$ tempo do teste em minutos, $\mathrm{T}$ a temperatura do gás, que foi considerada como $300 \mathrm{~K}$ e gpolinserido a massa de polímero que foi efetivamente usada no teste.

$\mathrm{Na}$ cromatografia gasosa, os valores de $\mathrm{CO}, \mathrm{CO}_{2}, \mathrm{~N}_{2}, \mathrm{O}_{2}$ e os hidrocarbonetos leves foram obtidos pelas áreas fornecidas nos resultados de cromatografia gasosa. Esses valores são comparados com as áreas obtidas na análise de padrões dos mesmos componentes, com concentrações conhecidas em pp\% para $\mathrm{CO}, \mathrm{CO}_{2}, \mathrm{~N}_{2}$ e $\mathrm{O}_{2}$ e partes por milhão (ppm) para os hidrocarbonetos.

A conversão de \%pp para $\mathrm{mg} / \mathrm{g}$ polímero inserido é feita seguindo a Equação 10. A conversão de ppm para $\mathrm{mg} / \mathrm{g}$ polímero é obtida pela seguinte equação:

$$
\frac{m g}{g P o l_{\text {inserido }}}=\frac{p p m}{1.000 .000} \cdot \frac{\text { vazaototal }_{\text {gas }}}{0,082 \cdot T(300 \mathrm{~K})} \cdot \frac{M M_{\text {gas }} \cdot 1000 \cdot t_{\text {teste }}}{g \text { Pol }_{\text {inserido }}} \quad \text { Equação } 11
$$

sendo ppm a concentração do componente em partes por milhão. 
Nos resultados que serão apresentados das emissões dos produtos de pirólise está excluída a diluição de $\operatorname{ar}\left(\mathrm{N}_{2} / \mathrm{O}_{2}\right)$ que ocorre no venturi. Desse cálculo, espera-se apresentar o resultado que seria obtido da coleta dos HL logo acima do venturi, na saída do forno de pirólise.

Os resultados obtidos pelas análises de PAH estão em $\mu \mathrm{g} / \mathrm{g}$ de polímero e, portanto, os resultados foram apenas divididos por 1000 para obter mg/g polímero inserido.

\subsubsection{Cálculo das porcentagens de fração mássica}

As porcentagens das frações mássicas dos componentes do gás foram calculadas a partir da quantidade em $\mathrm{mg} / \mathrm{g}$ de plástico inserido no forno. Exemplo: a $\%$ de fração mássica do xileno nos HL:

$$
\% \text { xileno }=\frac{\left(m g_{\text {xileno }} / g_{\text {pol }}\right)}{\left(m g_{\text {todos } H} / g_{\text {pol }}\right)} \cdot 100
$$

Equação 12

\subsubsection{Cálculo da razão equivalente}

Nos ensaios realizados há perda de plástico que se deposita (ou pela não vaporização, ou pela condensação de produtos líquidos e sólidos de reação) nas paredes do forno, nos flanges e conexões.

A razão equivalente pode ser calculada pela Equação 3. Pode-se verificar que essa razão depende da massa de combustível realmente envolvida no processo de combustão. Como ocorrem perdas, verificadas pelo balanço de massa, a razão equivalente calculada é maior que a razão equivalente dentro do forno.

$$
\phi=\frac{C A_{\text {real }}}{C A_{\text {estequiometrico }}}=\frac{\left(\frac{m_{\text {combustivel }}}{m_{\text {ar }}}\right)_{\text {real }}}{\left(\frac{m_{\text {combustivel }}}{m_{\text {ar }}}\right)_{\text {estequiometrico }}}
$$

Equação 3

Em razão disso, o cálculo da razão equivalente foi feito com base na quantidade de $\mathrm{CO}_{2}$ teórica e medida. Os gráficos das Figura 6 e Figura 7 foram feitos com base na reação de combustão teórica com diferentes proporções de combustível e ar, e calculando-se a produção de $\mathrm{CO}_{2}, \mathrm{CO}, \mathrm{H}_{2}$ e $\mathrm{H}_{2} \mathrm{O}$. Como a 
emissão de $\mathrm{CO}_{2}$ é uma das medidas mais confiáveis do teste, pode-se dizer que a concentração de $\mathrm{CO}_{2}$ medida na saída do forno é a concentração realmente existente dentro do forno e, portanto, a teórica. Essa concentração de $\mathrm{CO}_{2}$ corresponde a uma razão equivalente, que foi apresentada nos resultados dos testes, e este valor será sempre menor que a razão equivalente teórica do ensaio. 


\section{RESULTADOS E DISCUSSÃO}

Neste capítulo serão apresentados os resultados dos testes apresentados (pirólise, pirólise seguida de combustão e caracterização do material particulado). Serão discutidas as tendências em comum de cada polímero, quando existentes, em relação à temperatura e razão equivalente, depois apresentadas as particularidades de cada polímero, quando relevantes. Em seguida, será feita uma comparação com dados da literatura e discutidos os resultados como um todo.

\subsection{Emissões da pirólise}

\subsubsection{Hidrocarbonetos leves}

Vinte e três espécies de hidrocarbonetos foram identificadas e quantificadas na saída do forno de pirólise, que ficou mantido na temperatura de $1000^{\circ} \mathrm{C}$. As quantidades relativas dos compostos produzidos em maior quantidade, representando $90 \%$ do total de $\mathrm{HL}$ da pirólise do PE, e praticamente $100 \%$ na pirólise do PS estão mostradas na Figura 26. As quantidades emitidas dos outros compostos estão apresentadas no Anexo II.

a)

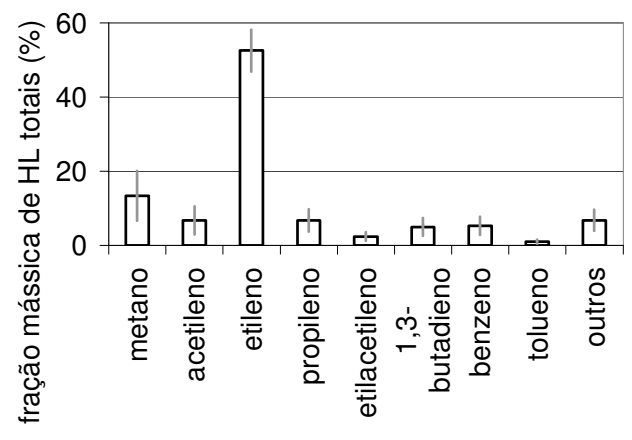

b)

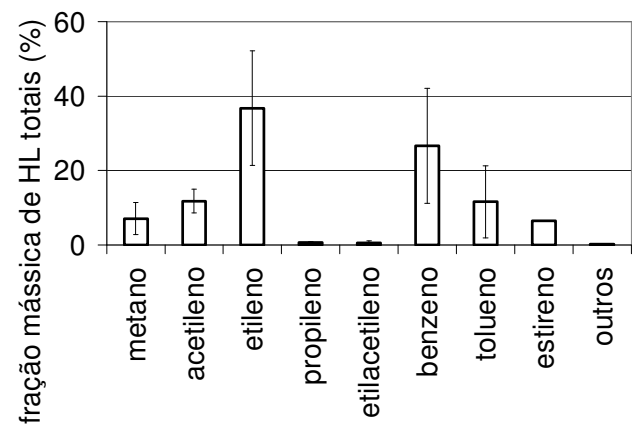

Figura 26 - Porcentagem da fração mássica dos HL da pirólise de a) PE e b) PS.

As emissões totais de $\mathrm{HL}$ e os compostos individuais estão apresentados na Figura 27 para o PE, e Figura 28 para o PS. As quantidades destas espécies gasosas diminuíram com o aumento da taxa de alimentação das partículas de 0,150,82 $\mathrm{g} / \mathrm{min}$ para o PE e 0,2-1,2g/min para o PS. Estas taxas de alimentação 
correspondem à razão equivalente no forno de oxidação para o PE de 0,3-1,4 e para o PS de 0,3-1,75.
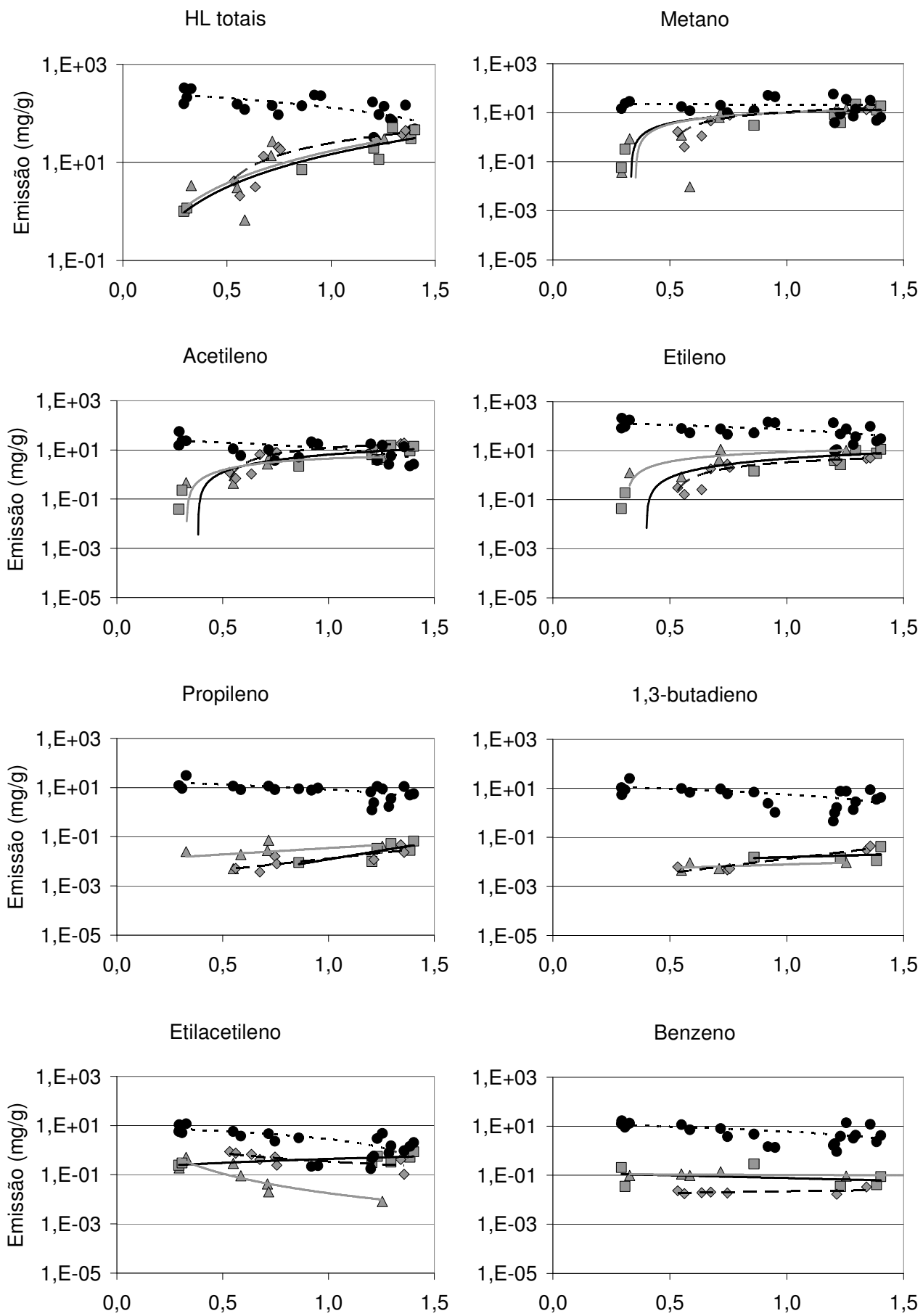
Tolueno

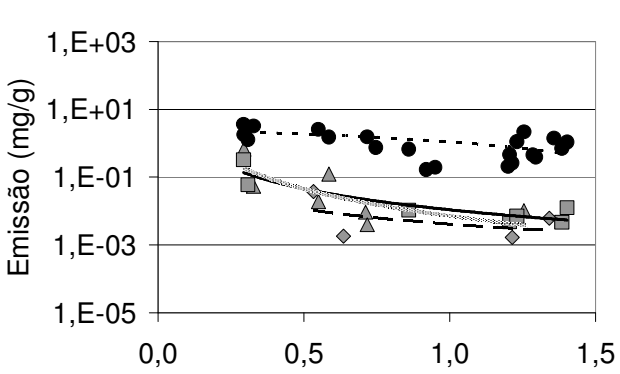

Benzaldeido

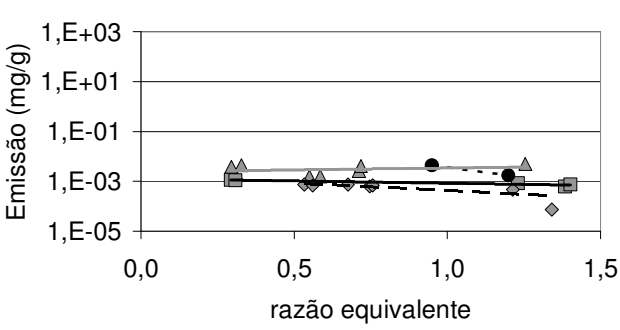

Estireno

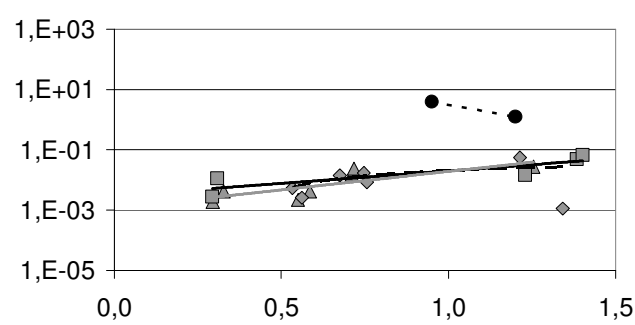

Fenol

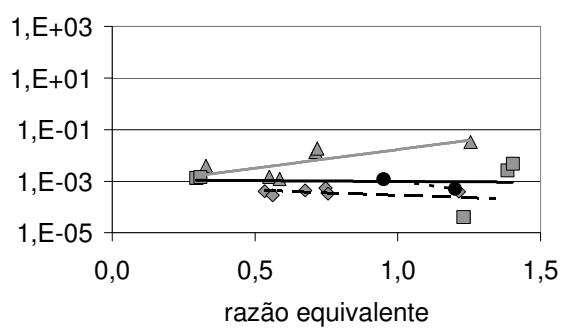

$\triangle$ combustão a $900^{\circ} \mathrm{C} \quad \square$ combustão a $1000^{\circ} \mathrm{C} \quad \diamond$ combustão a $1100^{\circ} \mathrm{C} \quad-$ - pirolise

Figura 27 - Emissão de HL total e individuais na pirólise e pirólise seguida de combustão de PE.

$\mathrm{HL}$ totais

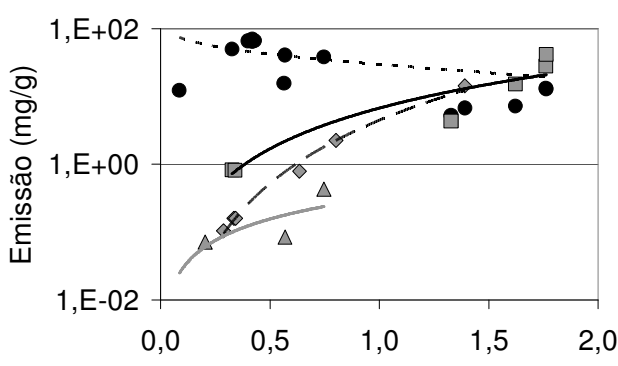

Acetileno

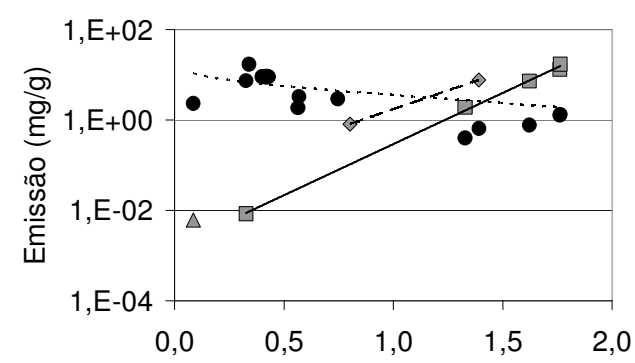

Metano

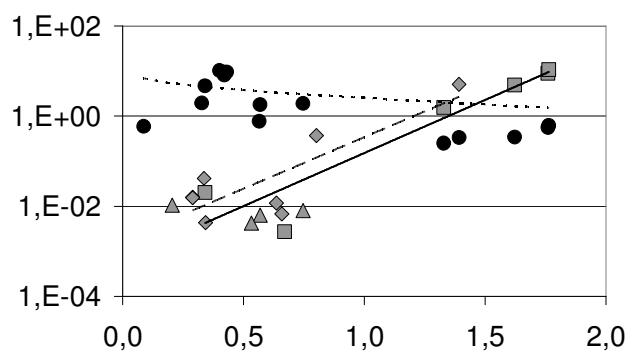

Etileno

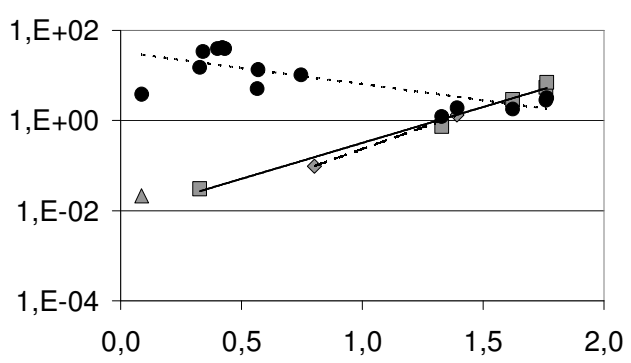


Propileno

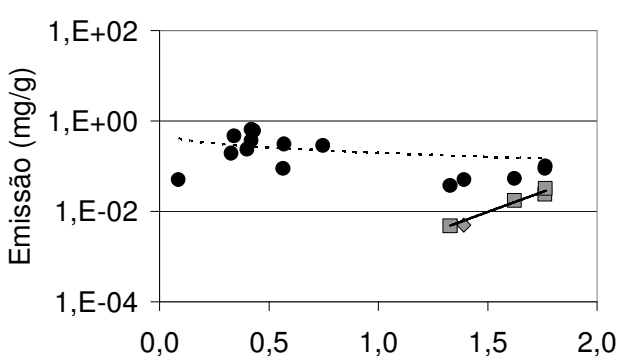

1,3-butadieno

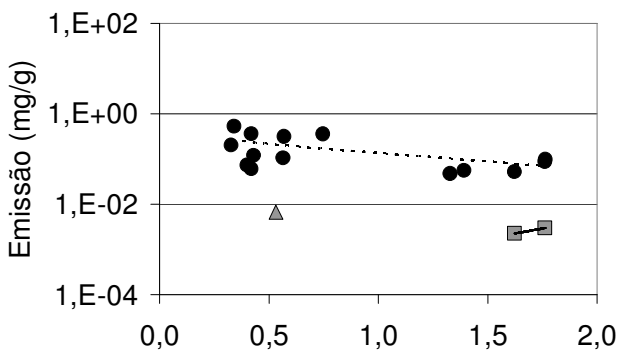

Tolueno

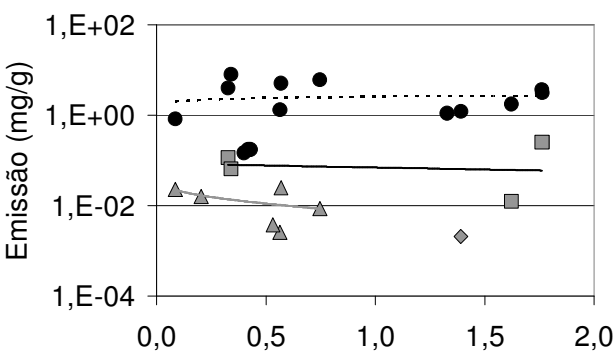

Benzaldeido

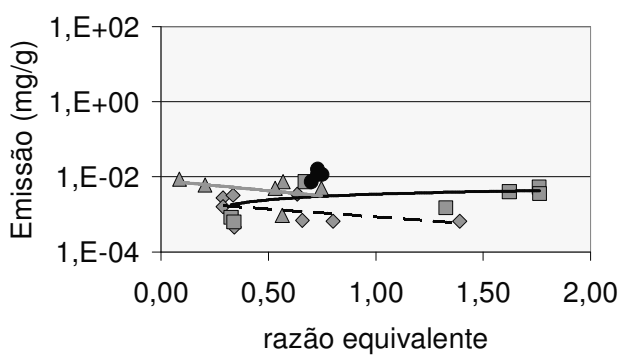

Etilacetileno

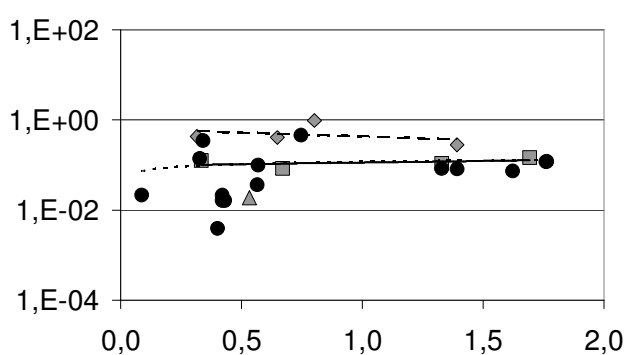

Benzeno

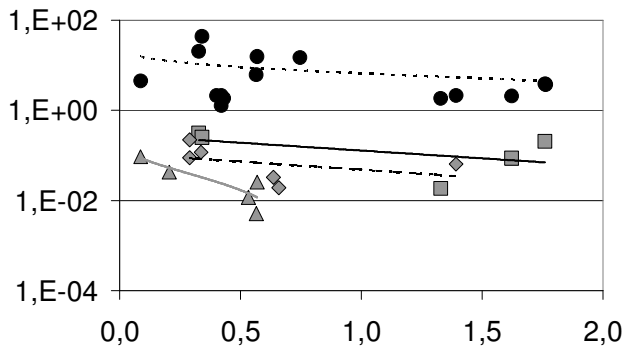

Estireno

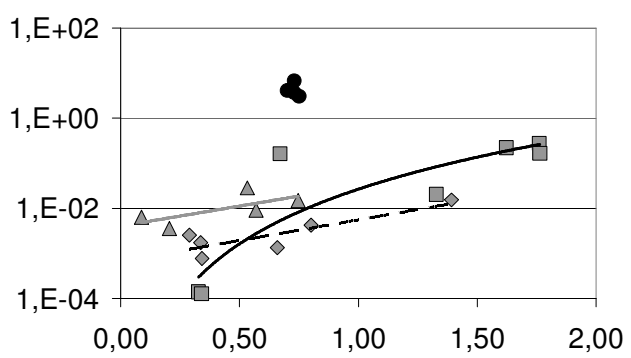

Fenol

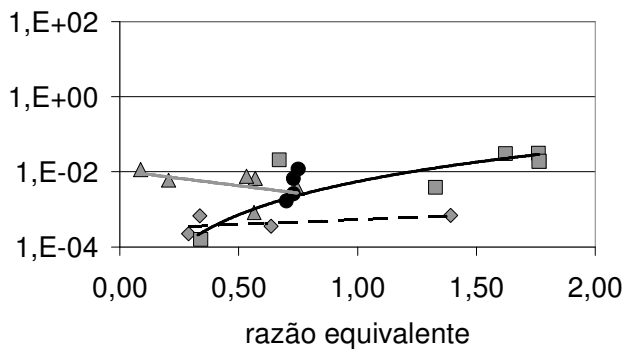

$\triangle$ combustão a $900^{\circ} \mathrm{C} \quad \square$ combustão a $1000^{\circ} \mathrm{C} \quad \diamond$ combustão a $1100^{\circ} \mathrm{C} \quad-$ - pirolise

Figura 28 - Emissão de HL total e individuais na pirólise e pirólise seguida de combustão de PS. 
O produto de pirólise de PE mostrou uma grande produção de etileno (ao redor de $50 \%$ da fração mássica dos $\mathrm{HL}$ ) e pequenas quantidades de outros compostos (ao redor de 15\% de metano e menos de $10 \%$ de cada um dos outros). Diferentemente, a pirólise de PS mostrou uma distribuição maior de HL, isto é, 35\% de etileno, $25 \%$ de benzeno, $12 \%$ de acetileno, $12 \%$ de tolueno e outros compostos em menor quantidade. 


\section{CONCLUSÕES}

Os resultados obtidos permitem concluir que:

- A quantidade emitida de $\mathrm{CO}_{2}$ foi praticamente estável em regiões pobres em combustível, e em $\phi>1$ decresceu.

- Não houve variação da quantidade emitida de $\mathrm{CO}_{2}$ em diferentes temperaturas para o PE. Na combustão do PS, a maior quantidade de $\mathrm{CO}_{2}$ foi detectada a $1100^{\circ} \mathrm{C}$, mostrando que uma emissão mais completa ocorreu;

- As emissões de CO aumentaram sensivelmente com o aumento da razão equivalente, em razão da maior quantidade de material que sofreu combustão para a mesma quantidade de gas comburente;

- Com o aumento da razão equivalente, a emissão total de HL e PAH da pirólise de PE diminuiu e a emissão total de HL e PAH da combustão de PE aumentou;

- O PAH produzido em maior quantidade no efluente da pirólise de PS foi o fenantreno.

- No efluente de combustão de PE, os compostos de HL e PAH mais emitidos foram o etileno e o naftaleno, respectivamente. No efluente de combustão do PS, os PAH mais emitidos foram o naftaleno, o acenaftileno e o fenantreno;

- A combustão de PE na temperatura de $1100^{\circ} \mathrm{C}$ resultou nas menores emissões de etileno, propileno e tolueno, mas nas maiores emissões de PAH e material particulado (em quantidade e tamanho de partículas);

- A combustão de PS na temperatura de $1100^{\circ} \mathrm{C}$ resultou nas menores emissões de PAH, exceto pelo antraceno;

- A maior parte dos PAH formados na pirólise de PE e PS foi minimizada depois da combustão em uma ordem de grandeza;

- A maior parte do material particulado produzido foi menor que $1 \mu \mathrm{m}$ (submicron).

- A combustão indireta das partículas de PE e PS minimizou as emissões de PAH e fuligem em 10 vezes, quando comparado com a maior parte dos casos de combustão direta;

No geral, a pirólise seguida da combustão se mostrou uma técnica favorável na minimização dos produtos de combustão incompleta, como o PAH e a fuligem. Esta técnica pode ser implementada para a recuperação do resíduo sólido plástico, 
diminuindo a quantidade disposta em aterros e lixões, e emitindo menos compostos poluentes para o meio ambiente. 


\section{REFERÊNCIAS}

1 ABRE - Associação Brasileira de Embalagem. Reciclagem no Brasil, 2004. Disponível em: <www.abre.org.br> Acesso em: 6 dez. 2006.

2 PANAGIOTOU , T.; LEVENDIS, Y. A.; CARLSON, J.; VOUROS, P. The Effect of Bulk Equivalence Ratio on the PAH Emissions from the Combustion of PVC, Poly(styrene) and Poly(ethylene), Proceedings Combustion Institute, v. 26, p. 2142-2460, 1996.

3 JINNO, D; GUPTA, A. K; YOSHIKAWA, K. Thermal destruction of plastic materials in solid waste, The proceedings of the 27th Int. Tech. Conf. on Coal Utilization \& Fuel Systems, 2002, 357-363.

4 ERGUT, A.; LEVENDIS, Y. A.; CARLSON, J. Emissions from the combustion of polystyrene, styrene and ethylbenzene. Fuel, 2007, em impressão.

5 CEMPRE - Compromisso Empresarial para Reciclagem, 2004. Microcenários setoriais sobre reciclagem no Brasil. Disponível em: <www.cempre.org.br $>$ Acesso em: 6 dez. 2006.

6 ANDRADY, A. L. Plastics and the environment, Hoboken, N.J. Wiley Interscience, 2003.

7 APC - American Plastic Council. Total sales \& captive use of selected thermoplastic resins by major market, 2001-2005. Disponível em: $<$ www.americanchemistry.com> Acesso em: 9 fev. 2007.

8 LUNDQUIST, L.; LETERRIER, Y.; SUNDERLAND, P.; MANSON, J. E. - Life Cicle Engineering of Plastics - Technology, economy and the environment, Oxford; N.Y., Elsevier, 2000.

9 EPA - Environmental Protection Agency. Municipal Solid Waste Generation, Recycling, and Disposal in the United States: Facts and Figures for 2003. Disponível em: <www.epa.gov> Acesso em: 05 ago. 2005. 
10 APME - Association of Plastic Manufacturers in Europe. An analysis of plastics consumption and recovery in Europe 2002-2003, Brussels (Belgium), 2004. Disponível em: <www.plasticseurope.org> Acesso em 26 nov. 2006.

11 Plastivida. Pesquisa de Mercado da reciclagem. Disponível em: $<$ www.plastivida.org.br> Acesso em 6 dez. 2006.

12 SUBRAMANIAN, P.M. Plastics Recycling and Waste Management in US, Resources, Conservation and Recycling. v. 28, p. 253-263, 2000.

13 The Environment and Industry Council (EPIC) Canadian Plastics Industry Association. The Gasification of Residual Plastics Derived from Municipal Recycling Facilities, August 2003. Disponivel em: <www.cpia.ca> Acesso: 14 jul. 2005.

14 Waste online. Plastics recycling informatio sheet. Disponível em:

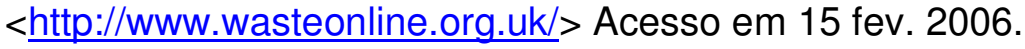

15 WANG, Z; RICHTER, H; HOWARD, J.B; JORDAN, J; CARLSON, J; LEVENDIS, $Y$. Laboratory investigation of the products of the incomplete combustion of waste plastics and techniques for their minimization - Ind. Eng. Chem. Res. v. 43, p. 28732886, 2004.

16 PANAGIOTOU, T. and LEVENDIS, Y.A. Observations on the combustion of polymers (plastics): from single particles to group of particles. Combust. Sci and Tech., v. 137, p.121-147, 1998.

17 SHEMWELL, B; LEVENDIS, Y.A. Particulates generated from combustion of polymers (plastics). J. Air and Waste Manage. Assoc., v. 50, p. 94-102, 2000.

18 WANG, Z.; WANG J.; RITCHER, H.; HOWARD, J.B.; CARLSON, J.; LEVENDIS, Y.A. Comparative Study on polycyclic aromatic hydrocarbons, light hydrocarbons, carbon monoxide, and particulate emissions from the combustion of polyethylene, polystyrene and polyvinylchloride. Energy and fuels, 17, 999-1013, 2003.

19 PANAGIOTOU, T.; LEVENDIS, Y.A.; CARLSON, J.; DUNAYEVSKIY, Y. M.; VOUROS, P. Aromatic hydrocarbon emissions from the burning poly(styrene), poly(ethylene), and PVC particles at high temperatures. Combust. Sci and Tech., v. 1116-117, p.91-128, 1996. 
20 CAPONERO, J. Reciclagem de Pneus. 2002. 164 p. Tese (doutorado) - Escola Politécnica, Universidade de São Paulo, SP, 2002.

21 NIESSEN, W. R. Combustion and incineration processes: applications in environmental engineering. N.Y., M. Dekker, 1995.

22 SCOTT, D. S.; CZERNIK, S. R.; PISKORZ, J.; RADLEIN, A.G. Fast Pyrolysis of Plastic Wastes. Energy \& Fuels, v. 4, p. 407-411, 1990.

23 WILLIAMS, P.T. and WILLIAMS, E.A. Interaction of Plastics in Mixed-Plastics Pyrolysis. Energy \& Fuels, v. 13, p. 188-196, 1999.

24 PARK, J.J.; PARK, K.; KIM, J.S.; MAKEN, S.; SONG, H.; SHIN, H.; PARK, J.W.; $\mathrm{CHOI}, \mathrm{M} . J$. Characterization of styrene recovery from the pyrolysis of waste expandable polystyrene. Energy and Fuels, v. 17, p.1576-1582, 2003.

25 BOCKHORN, H.; HORNUNG, A.; HORNUNG, U. Gasification of Polystyrene as initial step in incineration, fires, or smoldering of plastics. $27^{\circ}$ Symposium (International) on Combustion/The combustion Institute, p. 1343-1349, 1998.

26 KAMINSKY, W.; PREDEL, M. and SADIKI, A. Feedstock recycling of polymers by Pyrolysis in a fluidized bed. Polymer Degradation and Stability, v. 85, p. 10451050, 2004.

27 BAYLER, G. Handbook of Fire Protection Engineering, Society of Fire Protection Engineers (National Fire Protection Association, Eds.), Quincy, MA, p. 165-187, 1988.

28 WESTERHOUT, R. W. J.; WAANDERS, J.; KUIPERS, J. A. M.; van SWAAIJ, W. P. M. Recycling of Polyethylene and Polypropylene in a Novel Bench-Scale Rotating Cone Reactor by High Temperature Pyrolysis. Ind. Eng. Chem. Res. v. 37, p. 22932300, 1998.

29 KAMINSKY, W. Pyrolysis of plastic waste and scrap tyres in a fluid bed reactor. Resource Recovery and Conservation, v. 5, p. 205-216, 1980. 
30 BALLICE, L; YÜKSEL, M; SaGLAM, M. Classification of volatile products from the temperature-programmed pyrolysis of low and high density polyethylene. Energy and fuels, v. 12, p. 925-928, 1998.

31 CONESA, J. A.; FONT, R. and MARCILLA, A. Comparison between the Pyrolysis of Two Types of Polyethylenes in a Fluidized Bed Reactor. Energy \& Fuels, v. 11, p. 126-136, 1997.

32 CONESA, J. A.; FONT, R.; MARCILLA, A. and GARCIA, A. N. Pyrolysis of Polyethylene in a Fluidized Bed Reactor. Energy \& Fuels, v. 8, p. 1238-1246, 1994.

33 MASTRAL, J. F.; BERRUECO, C. and CEAMANOS, J. Pyrolysis of high-density polyethylene in free-fall reactors in series. Energy \& Fuels, v. 20, p. 1365-1371, 2006.

34 ÇENGEL, Y. A. and BOLES, M A. Thermodynamics: an engineering approach, $2^{\circ}$ ed., N. Y., McGraw-Hill, p. 733-780, local, 1994.

35 LICHTY, L. C. Combustion Engine Processes, N. Y., McGraw-Hill, $6^{\circ}$ ed., p. 6191, 1967.

36 WARNATZ, J. Combustion : physical and chemical fundamentals, modeling and simulation, experiments, pollutant formation / J. Warnatz, U. Maas, R.W. Dibble, Berlin, N. Y., Springer, $3^{\circ}$ ed., 2001.

37. THEODORE, L.; REYNOLDS, J. Introduction to Hazardous Waste Incineration, $1^{\circ}$ ed., John Wiley \& Sons Inc., New York, 1987.

38 HEYWOOD, J. B. Internal Combustion Engine Fundamentals, N. Y., McGraw-Hill, p. 592-661, 1988.

39 LONGWELL, J. P. The formation of polycyclic aromatic hydrocarbons by combustion, in: 19th Symposium (International) on Combustion, The combustion Institute, p. 1339-1350, 1982.

40 FRENKLACH, M. Reaction mechanism of soot formation in flames. Phys. Chem. Chem. Phys., v. 4, p. 2028-2037, 2002. 
41 RITCHER, H; HOWARD, J. B. Formation of polycyclic aromatic hydrocarbons and their growth to soot - a review of chemical reaction pathways, Progress in Energy and combustion science, v. 20, p. 565-608, 2000.

42 EPA - US environmental Protection Agency. Health and Environmental Effects of Particulate Matter. Disponível em: <www.epa.gov> Acesso em 29 jan. 2007.

43 McENALLY, C. S.; PFEFFERLE, L. D.; ATAKAN, B.; HÖINGHAUS, K. K. Studies of aromatic hydrocarbon formation mechanisms in flames: progress towards closing the fuel gap. Progress in Energy \& Combustion Science, v. 32, p. 247-294, 2006.

44 HEYWOOD, J. B. Internal combustion engine fundamentals, N.Y., McGraw-Hill, p. 89-90, 1988.

45 FONT, R; ARACIL, I; FULLANA, A; CONESA, J.A Semivolatile and volatile compounds in combustion of PE. Chemosphere, v. 57, p. 615-627, 2004.

46 WANG, J; LEVENDIS, Y; RICHTER, H; HOWARD, J.B; CARLSON, J. Polycyclic aromatic hydrocarbon and particulate emissions from two-stage combustion of polystyrene: the effect of the primary furnace temperature. Environ. Sci. Technol., v. 35, p. $3541-3552,2001$.

47 WANG, J; RICHTER, H; HOWARD, J.B; LEVENDIS, Y; CARLSON, J. Polynuclear aromatic hydrocarbon and particulate emissions from two-stage combustion of polystyrene: the effects of the secondary furnace (afterburner) temperature and soot filtration. Environ. Sci. Technol., v. 36, p. 797-808, 2002.

48 WESTBLAD, C.; LEVENDIS, Y.; RITCHER, H.; HOWARD, J.; CARLSON, J. A. Study on toxic organic emissions from batch combustion of styrene. Chemosphere, v. 49 , p. $395-412,2002$.

49 DURLAK, S. K.; BISWAS, P.; SHI, J.; BERNHARD, M. J. Characterization of polycyclic aromatic hydrocarbon particulate and gaseous emissions from polystyrene combustion. Environ. Sci. Technol., v. 32, p. 2301-2307, 1998.

50 COURTEMANCHE, B.; LEVENDIS, Y. A. A laboratory study on the NO, $\mathrm{NO}_{2}$, $\mathrm{SO} 2, \mathrm{CO}$ and $\mathrm{CO} 2$ emissions from the combustion of pulverized coal, municipal waste plastics and tires. Fuels, v. 77, n. 3, p. 183-196, 1998. 
51 PANTALONE, J. C.; ERGUT, A.; LEVENDIS, Y. A. Experimental and numerical study of emissions from fuel-rich combustion of pulverized polystyrene. Combustion Science and Technology, v. 178, n. 7, p. 1297-1324, 2006.

52 ERGUT, A; LEVENDIS, Y; CARLSON, J. Comparison of products of incomplete combustion of waste polystyrene and styrene in diffusion flames and ethyl benzene in fuel-rich premixed flames. Proceedings of ASME POWER 2004, March 30, Baltimore, Maryland USA, 2004.

53 DeCOSTER, J.; ERGUT, A.; LEVENDIS, Y. A.; RITCHER, H.; HOWARD, J. B.; CARLSON, J. B. PAH emissions from high-temperature oxidation of vaporized anthracene. Proceedings of the Combustion Institute (2006), em impressão.

54 CUMPER, J. G.; LEVENDIS, Y. A. and METGHALCHI, M. Characterization of the Environment in a Laminar Flow Furnace with Applications to the Combustion of Coal and Coal-Water Slurries, ASME publication HTD, v. 148, p. 89-96, 1990.

55 DARIVAKIS, G. S.; HOWARD; J. B. ; PETERS, W. A. Release Rates of Condensables and Total Volatiles from Rapid Devolatilization of Polyethylene and Polystyrene. Combustion Science and Technology, v. 74, p. 267-281, 1990. 